\title{
Metallic iron for water treatment: leaving the valley of confusion
}

\author{
Susanne Makota $^{1} \cdot$ Arnaud I. Nde-Tchoupe $^{1} \cdot$ Hezron T. Mwakabona ${ }^{2,3,7}$. \\ Raoul Tepong-Tsindé ${ }^{1,4} \cdot$ Chicgoua Noubactep ${ }^{1,4,5,6} \cdot$ Achille Nassi $^{1}$. \\ Karoli N. Njau ${ }^{7}$
}

Received: 19 September 2016/Accepted: 20 July 2017/Published online: 31 July 2017

(C) The Author(s) 2017. This article is an open access publication

\begin{abstract}
Researchers on metallic iron $\left(\mathrm{Fe}^{0}\right)$ for environmental remediation and water treatment are walking in a valley of confusion for 25 years. This valley is characterized by the propagation of different beliefs that have resulted from a partial analysis of the $\mathrm{Fe}^{0} / \mathrm{H}_{2} \mathrm{O}$ system as (1) a reductive chemical reaction was considered an electrochemical one and (2) the mass balance of iron has not been really addressed. The partial analysis in turn has been undermining the scientific method while discouraging any real critical argumentation. This communication re-establishes the complex nature of the $\mathrm{Fe}^{0} / \mathrm{H}_{2} \mathrm{O}$ system while recalling that, finally, proper system analysis and chemical thermodynamics are the most confident ways to solve any conflicting situation in $\mathrm{Fe}^{0}$ environmental remediation.
\end{abstract}

Chicgoua Noubactep

cnoubac@gwdg.de

Susanne Makota

s.makota@laposte.net

Arnaud I. Nde-Tchoupe

arnauldigor@yahoo.com

Hezron T. Mwakabona

mwakabona@gmail.com

Raoul Tepong-Tsindé

raoultepong@googlemail.com

Achille Nassi

achillen@yahoo.fr

Karoli N. Njau

karoli.njau@nm-aist.ac.tz

1 Department of Chemistry, Faculty of Sciences, University of Douala, B.P. 24157 Douala, Cameroon

2 Department of Physical Sciences, Sokoine University of Agriculture, Morogoro, PO Box 3038, Tanzania
Keywords Mainstream science - Valley of confusion · Water treatment $\cdot$ Zero-valent iron

\section{Preliminary remarks}

Metallic iron $\left(\mathrm{Fe}^{0}\right)$ is increasingly used for water treatment and environmental remediation $\left(\mathrm{Fe}^{0} / \mathrm{H}_{2} \mathrm{O}\right.$ system $)$ (Madaffari, 2015; Chen et al. 2017; Gatcha-Bandjun et al. 2017: Mwakabona et al. 2017; Song et al. 2017, Yang et al. 2017). There are many recent review articles concerning investigations on the $\mathrm{Fe}^{0} / \mathrm{H}_{2} \mathrm{O}$ system, including $\mathrm{Fe}^{0}$ composites and nano- $\mathrm{Fe}^{0}$. Recently raised critical comments on advances in research on the $\mathrm{Fe}^{0} / \mathrm{H}_{2} \mathrm{O}$ system (Noubactep 2015) have not been properly considered ( $\mathrm{Li}$

3 Department of Chemical Engineering, Faculty of Engineering Sciences, Katholieke Universiteit Leuven, Louvain, Belgium

4 Department of Applied Geology, Universität Göttingen, Goldschmidtstraße 3, 37077 Göttingen, Germany

5 Comité Afro-européen, Avenue Léopold II, Namur 41-5000, Belgium

6 Kultur und Nachhaltige Entwicklung CDD e.V, Postfach 1502, 37005 Göttingen, Germany

7 Department of Water and Environmental Science and Engineering, Nelson Mandela African Institution of Science and Technology, Arusha, P.O. Box 447, Tanzania 
et al. 2015; Guo et al. 2016; Raman and Kanmani 2016; Sleiman et al. 2016; Kumar and Sinha 2017). Typically, Noubactep (2015) and references criticized therein are cited in the same set of available review articles, without any further specification. This suggests that more explanation is needed to convince active researchers to move environmental research on the $\mathrm{Fe}^{0} / \mathrm{H}_{2} \mathrm{O}$ system to the mainstream science. The present article is regarded as an extension of Noubactep (2015) and provides some directions to be reconsidered in this field. Only a proper consideration of hints given herein would enable an open collaborative research aiming at: (1) providing more insightful evidence on the structure/activity relationship within the $\mathrm{Fe}^{0} / \mathrm{H}_{2} \mathrm{O}$ system, (2) characterizing the thermodynamic and kinetic of the $\mathrm{Fe}^{0} / \mathrm{H}_{2} \mathrm{O}$ system as influenced by relevant operational conditions, and (3) facilitating the design and operation of pilot scale tests to prepare more efficient (affordable) and sustainable $\mathrm{Fe}^{0}$ based systems for water treatment and environmental remediation (Mwakabona et al. 2017; Naseri et al. 2017).

\section{Introduction}

The last two decades have witnessed the establishment of metallic iron $\left(\mathrm{Fe}^{0}\right)$ as an excellent filling material for filtration systems in environmental remediation and water treatment (O’Hannesin and Gillham 1998; Scherer et al. 2000; Richardson and Nicklow 2002; Henderson and Demond, 2007; Cundy et al. 2008; Thiruvenkatachari et al. 2008; Comba et al. 2011; Gheju 2011; Naidu 2013; Fu et al. 2014; Obiri-Nyarko et al. 2014; Guan et al. 2015; Naidu and Birke 2015; Noubactep 2015; Guo et al. 2016; Karottu-Ansaf et al. 2016; Zou et al. 2016). In this context, $\mathrm{Fe}^{0}$ is currently regarded as (1) a reductant for some species, (2) an adsorbent for other species, (3) a coagulant for various anionic species (Richardson and Nicklow 2002; Noubactep 2010a; Shrimpton et al. 2015; Lu et al. 2016; Sun et al. 2016; Xu et al. 2016) and (4) a long-term supplier of $\mathrm{Fe}^{2+}$ for activation of oxidation processes (Liang and Guo 2010; Segura et al. 2015; Lee et al. 2014; Lin et al. 2016). The properties making $\mathrm{Fe}^{0}$ suitable for environmental remediation include: (1) its readily availability and (2) its environmental friendliness implying the generation of non-toxic hydroxides and oxides. Contaminants that have been successfully removed from aqueous solutions in the presence of $\mathrm{Fe}^{0}$ include arsenic, bacteria, bromate, chromate, dyes, halogenated organics, mercury, nitrate, nitroaromatics, pesticides, phenolic compounds, phosphates, selenium, uranium, viruses and zinc (Richardson and Nicklow 2002; Henderson and Demond 2007; Guan et al. 2015; Naidu and Birke 2015; Zou et al. 2016).
The literature on using metallic iron $\left(\mathrm{Fe}^{0}\right)$ for environmental remediation and water treatment (e.g., the $\mathrm{Fe}^{0} / \mathrm{H}_{2} \mathrm{O}$ system) is a richly confused one (Ghauch 2015; Nkundimana et al. 2015; Noubactep 2015; Gheju et al. 2016; Noubactep 2016a). The ancient use of $\mathrm{Fe}^{0}$ for safe drinking water provision both at household (Bischof 1877, 1878; Baker 1934) and large scale (Devonshire 1890; Baker 1934; Van Craenenbroeck 1998) levels has been widely overseen (Mwakabona et al. 2017). The redox complex geochemistry of iron (Table 1) probably constitutes the main reason why the $\mathrm{Fe}^{0} / \mathrm{H}_{2} \mathrm{O}$ system has received such varied attention. In fact, $\mathrm{Fe}^{0}$ is oxidized by water to form $\mathrm{Fe}^{\mathrm{II}}$ species (Eq. 8) that are further transformed to $\mathrm{Fe}^{\mathrm{III}}$ species and mixed $\mathrm{Fe}^{\mathrm{II}} / \mathrm{Fe}^{\mathrm{III}}$ species including hydroxides and oxides (Eq. 10) (Liu and Millero 1999; Nesic 2007; Antia 2010; Noubactep 2010a, b, c; Luo et al. 2013; Noubactep 2016b, c, d, e; van Genuchten et al. 2016). The difference in the crystal structure of $\mathrm{Fe}^{0}$ and generated corrosion products (Table 2) implies that the oxide scale is not primarily a protective one (Lazzari 2008; Noubactep 2010c).

Generated $\mathrm{Fe}^{\mathrm{III}}$ species can be transformed back to $\mathrm{Fe}^{\mathrm{II}}$ species. The whole process is sustained by microorganisms and in situ generated nascent mineral surfaces (Matheson and Tratnyek, 1994; Pokhrel et al. 2005; Pokhrel and Viraraghavan 2008; Pokhrel et al. 2009; Pokhrel and Viraraghavan 2009). $\mathrm{Fe}^{0}$ oxidation by water also generates $\mathrm{H}_{2}$ (Eq. 8) (Lackovic et al. 2000; Han et al. 2016; Noubactep 2016a, d, e). As summarized, the $\mathrm{Fe}^{0} / \mathrm{H}_{2} \mathrm{O}$ system contains (1) oxidizing agents (e.g., $\mathrm{Fe}^{\mathrm{III}}$ species), (2) reducing agents (e.g., $\mathrm{H}_{2}, \mathrm{Fe}^{\mathrm{II}}, \mathrm{Fe}_{3} \mathrm{O}_{4}$ ) and (3) adsorbing agents (e.g., hydroxides and oxides) acting in synergy. $\mathrm{Fe}^{0}$ can also be specifically used to generate $\mathrm{Fe}^{\mathrm{II}} / \mathrm{Fe}^{\mathrm{III}}$ (Khan et al. 2000; Noubactep 2016d; Gottinger et al. 2013), $\mathrm{H}_{2}$ (Reardon 1995, 2005), or hydroxides and oxides (Karschunke et al. 2000; Khan et al. 2000). In another phrase, in an $\mathrm{Fe}^{0} / \mathrm{H}_{2} \mathrm{O}$ system a contaminant can be adsorbed, oxidized or/and reduced depending on its affinities to available mineral phases and its chemical reactivity with other species. It is also understood that the surface of $\mathrm{Fe}$ minerals possesses catalytic properties for relevant reactions (Furukawa et al. 2002; Richardson and Nicklow 2002; Jia et al. 2007; Jiao et al. 2009; Noubactep 2009a; Ghauch et al. 2010; Ghauch et al. 2011; Gheju and Balcu 2011; Ghauch, 2015; Gheju et al. 2016). However, at concentration levels relevant for natural waters, contaminants are removed from the aqueous phase by (1) adsorption, (2) co-precipitation and (3) size-exclusion (Pokhrel and Viraraghavan 2008; Noubactep 2011b; Luo et al. 2013; Ndé-Tchoupé et al. 2015; Tepong-Tsindé et al. 2015a; b; Noubactep 2016a) (Table 3). 
Table 1 Electrode potential of redox couples relevant for processes yielding contaminant removal in $\mathrm{Fe}^{0} / \mathrm{H}_{2} \mathrm{O}$ systems (Eq. 1 through Eq. 5)

\begin{tabular}{ll}
\hline Electrode reaction & $\mathrm{E}^{0}(\mathrm{~V})$ \\
\hline $\mathrm{Fe}^{2+}+2 \mathrm{e}^{-} \Leftrightarrow \mathrm{Fe}^{0}$ & -0.44 \\
$\mathrm{Fe}_{(\mathrm{s})}^{3+}+\mathrm{e}^{-} \Leftrightarrow \mathrm{Fe}_{(\mathrm{s})}^{2+}$ & -0.34 to -0.65 \\
$2 \mathrm{H}^{+}+2 \mathrm{e}^{-} \Leftrightarrow \mathrm{H}_{2}$ & 0.00 \\
$\mathrm{Fe}_{(\mathrm{aq})}^{3+}+\mathrm{e}^{-} \Leftrightarrow \mathrm{Fe}_{(\text {aq) }}^{2+}$ & 0.77 \\
$\mathrm{O}_{2}+2 \mathrm{H}^{+}+2 \mathrm{e}^{-} \Leftrightarrow 2 \mathrm{OH}^{-}$ & 0.81 \\
$\mathrm{Fe}^{0}+\mathrm{O}_{2}+2 \mathrm{H}^{+} \Leftrightarrow \mathrm{Fe}^{2+}+\mathrm{OH}^{-}$ & - \\
$\mathrm{Fe}^{0}+2 \mathrm{Fe}_{(\mathrm{aq})}^{3+} \Rightarrow 3 \mathrm{Fe}_{(\text {aqors }}^{2+}$ & - \\
$\mathrm{Fe}^{0}+2 \mathrm{H}^{+} \Leftrightarrow \mathrm{Fe}^{2+}+\mathrm{H}_{2}$ & - \\
$\mathrm{Fe}^{0}+2 \mathrm{Fe}_{(\mathrm{s})}^{3+} \Rightarrow 3 \mathrm{Fe}_{(\text {aqors }}^{2+}$ & - \\
$\mathrm{Fe}^{2+}, \mathrm{Fe}^{3+}, \mathrm{H}_{2} \mathrm{O}, \mathrm{O}_{2} \Leftrightarrow \mathrm{Fe}^{\mathrm{II}} / \mathrm{Fe}^{\mathrm{III}}$ (hydr)oxides & -
\end{tabular}

The resulting chemical reactions implying $\mathrm{Fe}^{0}$ are specified of which only Eq. 8 and Eq. 9 are electrochemical in nature. $\mathrm{Fe}^{0}$ oxidation after Eq. 9 is not likely to be quantitative. The reaction after Eq. 6 is not possible/quantitative because the $\mathrm{Fe}^{0}$ surface is not accessible to $\mathrm{O}_{2}$. $\mathrm{O}_{2}$ is reduced rather by Fe ${ }^{\mathrm{II}}$ species (Eq. 2 and Eq. 4). Electrode potential values are given versus the Standard Hydrogen Electrode (SHE)

Table 2 Selected physical and chemical characteristics of some iron minerals relevant for environmental $\mathrm{Fe}^{0} / \mathrm{H}_{2} \mathrm{O}$ systems

\begin{tabular}{llllll}
\hline Species & Formula & Symmetry & Magnetism & Density $\left(\mathrm{g} \mathrm{cm}^{-3}\right)$ & Color \\
\hline Iron & $\mathrm{Fe}$ & bcc & - & 7.86 & Gray \\
Magnetite & $\mathrm{Fe}_{3} \mathrm{O}_{4}$ & Cubic & fim & 5.18 & Black \\
Hematite & $\alpha-\mathrm{Fe}_{2} \mathrm{O}_{3}$ & Trigonal & wfm or efm & 5.26 & Red \\
Maghemite & $\gamma-\mathrm{Fe}_{2} \mathrm{O}_{3}$ & Cubic & fim & 4.87 & Reddish-brown \\
Goethite & $\alpha-\mathrm{FeOOH}$ & Orthorhombic & afm & 4.26 & Yellow-brown \\
Lepidocrocite & $\gamma-\mathrm{FeOOH}$ & Orthorhombic & afm & 4.09 & Orange \\
Ferrihydrite & $\mathrm{Fe}_{1.55} \mathrm{O}_{1.66}(\mathrm{OH})_{1.34}$ & Hexagonal & sp & 3.96 & Red-brown \\
\hline
\end{tabular}

Noubactep (2010a) argues that the variability of crystal systems of $\mathrm{Fe}^{0}$ and iron minerals is the main reason for the suitability of $\mathrm{Fe}^{0}$ for environmental remediation. Adapted from Noubactep (2010a)

$w f m$ weekly ferromagnetic, $a f m$ antiferromagnetic, fim ferrimagnetic, $s p$ speromagnetic

Hundreds of students enrolled in research on the $\mathrm{Fe}^{0}$ / $\mathrm{H}_{2} \mathrm{O}$ system try to exploit (e.g., critically review) the abundant $\mathrm{Fe}^{0}$ literature (Tratnyek 2002) in order to identify knowledge gaps to be filled by own contributions. This review process often involves struggles with confusion, which certainly has an adverse effect on the own research idea, leading to more confusing papers in the scientific literature (Ghauch 2015; Noubactep 2015, 2016a). A survey of the $\mathrm{Fe}^{0}$ literature reveals that confusion is the rule and not the exception ("Common confusions regarding the $\mathrm{Fe}^{0} / \mathrm{H}_{2} \mathrm{O}$ system") (Sarr 2001; Henderson and Demond 2007; Lee et al. 2004; Comba et al. 2011; Gheju 2011; Fu et al. 2014; Obiri-Nyarko et al. 2014; Ghauch 2015; Naidu and Birke 2015; Noubactep 2015, 2016a, b; Zou et al. 2016). It is obvious that the more confusion the researchers are exposed to, the lower the quality of their results. Accordingly, the resolution of confusion helps mitigate this effect and improve the scientific quality of resulting publications. Herein, the most common confusions of the $\mathrm{Fe}^{0}$ literature are explored for the sake of more clarity within the $\mathrm{Fe}^{0}$ research community.

\section{Common confusions regarding the $\mathrm{Fe}^{0} / \mathrm{H}_{2} \mathrm{O}$ system}

A profound understanding of interactions in $\mathrm{Fe}^{0} / \mathrm{H}_{2} \mathrm{O}$ systems yielding water treatment is essential for enhancing the design of $\mathrm{Fe}^{0}$ filters (Sarr 2001; Lee et al. 2004; Li et al. 2006; Henderson and Demond 2011; Ulsamer 2011; Caré et al. 2013; Rahman et al. 2013; Guan et al. 2015). Information regarding $\mathrm{Fe}^{0}$ reactivity and interactions in $\mathrm{Fe}^{0} / \mathrm{H}_{2} \mathrm{O}$ system is highly conflicting (Furukawa et al. 2002. Bartzas and Komnitsas 2010; Li and Benson 2010; Domga et al. 2015; Guan et al. 2015; Noubactep 2015). A recent critical review on 20 years research on 'applying $\mathrm{Fe}^{0}$ in contaminant removal' (Guan et al. 2015) was proven confusing as many factors conventionally discussed as limitations of the technology are its true strengths (Ghauch 2015; Noubactep 2015, 2016a, b). The first of these factors is the presence of an oxide scale on $\mathrm{Fe}^{0}$ which is usually presented as the cause of reactivity loss (Mackenzie et al. 1999; Henderson and Demond, 2007; Guan et al. 2015). Together with permeability loss, reactivity loss is the 
Table 3 Main groups of biological and chemical contaminants that have been successfully treated by $\mathrm{Fe}^{0} / \mathrm{H}_{2} \mathrm{O}$ systems (batch and column studies)

\begin{tabular}{lll}
\hline Compounds & Examples & Removal mechanism \\
\hline $\mathrm{RCl}$ & Methanes, ethanes, ethenes, propanes & Red, degradation, adsorption \\
Aromatics & Catechol, nitrobenzene, resorcinol & Red, degradation, adsorption \\
Dyes & Methylene blue,methlyorange, orange II & Red, degradation, adsorption \\
Anions & Arsenic, nitrate, phosphate, sulfate & Adsorption, co-precipitation \\
Heavy metals & Cd, Co, Cu, Cr, Fe, Mn, Ni, Pb, Se, Tc, U, Zn & Red, precipitation, adsorption \\
Pathogens & Bacteria, Protozoa, and Viruses & Adsorption, co-precipitation \\
Pharmaceuticals & e.g., Aminophylline, Paracetamol, Tramadol & Red, degradation, adsorption \\
\hline
\end{tabular}

The reported major removal mechanisms are specified. The presentation herein recalls that adsorption, co-precipitation and size-exclusion are the fundamental removal processes. $\mathrm{RCl}$ stands for an halogenated hydrocarbon

major concern on the sustainability of $\mathrm{Fe}^{0}$ filters (Henderson and Demond 2007; Guan et al. 2015; Moraci et al. 2016). However, if the presence of an oxide scale on $\mathrm{Fe}^{0}$ was such a huge problem, $\mathrm{Fe}^{0}$ would never be used for any decontamination system at $\mathrm{pH}$ values of natural waters $(\mathrm{pH}>4.5)$. This $\mathrm{pH}$ range corresponds to the lowest solubility of iron (both $\mathrm{Fe}^{\mathrm{II}}$ and $\mathrm{Fe}^{\mathrm{III}}$ ) in water (Liu and Millero 1999; Ghauch 2015). Thus, iron precipitation cannot be avoided. Moreover, if the oxide scale on $\mathrm{Fe}^{0}$ was a problem, $\mathrm{Fe}^{0}$ filters would not have worked for more than 10 years (Phillips et al. 2010; Wilkin et al. 2014; Naidu and Birke 2015).

The present work will not replicate the related discussion extensively presented in the peer-reviewed literature since 2007 (Noubactep 2007, 2008, 2010c, d, 2012a, b, 2013a, b, c, 2014a, b; Ghauch 2015) and summarized in Noubactep (2015). Rather, the focus is on the key points that had led to the most significant confusions. Clearly, it is not discussed herein why discrepant data have been presented but rather mainly where discrepancies come from. It is understood that the origin of controversial reports is that falsehoods were introduced into the information stream of iron corrosion science as $\mathrm{Fe}^{0}$ was considered an own reducing agent under environmental conditions (Noubactep 2007, 2008). The current stand is that misconceptions are so widely propagated that the path back to mainstream science could be regarded as moving 'against the tide' (Noubactep 2015, 2016b).

The most important discrepancies regard (1) the mechanism of contaminant removal in $\mathrm{Fe}^{0} / \mathrm{H}_{2} \mathrm{O}$ systems, (2) the use of nano-scale materials, (3) the sustainability of hybrid systems and (4) the design of $\mathrm{Fe}^{0}$ filters. These main issues are interrelated and can be subdivided into several aspects. The next section gives a short comment on twelve selected aspects by identifying their origin and suggest ways out of the valley of confusion.

\section{Fixing confusions in $\mathrm{Fe}^{0} / \mathrm{H}_{2} \mathrm{O}$ systems}

\section{Contaminant removal mechanisms in $\mathrm{Fe}^{0} / \mathrm{H}_{2} \mathrm{O}$ systems}

The $\mathrm{Fe}^{0}$ technology for water treatment was introduced with the view that $\mathrm{Fe}^{0}$ oxidative dissolution is mediated by contaminant reduction (Matheson and Tratnyek 1994; Weber 1996; Gheju and Balcu 2011; Han et al. 2016). This view supposes that contaminant reduction is the cathodic reaction simultaneous to $\mathrm{Fe}^{0}$ oxidation (Eq. 11) (Ghauch 2015; Noubactep 2016a, b). RCl stands for a chlorinated hydrocarbon.

$\mathrm{Fe}^{0}+\mathrm{RCl}+2 \mathrm{H}^{+} \rightarrow \mathrm{Fe}^{2+}+\mathrm{RH}+\mathrm{HCl}$.

This view obviously degrades $\mathrm{Fe}^{0}$ corrosion by water (Eq. 8) to a side reaction although water is the solvent $\left(\left[\mathrm{H}_{2} \mathrm{O}\right]=55.5 \mathrm{~mol} \mathrm{~L}^{-1}\right)$ and has been documented a standalone corrosive agent both in the open corrosion literature (Stratmann and Müller 1994; Nesic 2007; Alamilla et al. 2009) and in the $\mathrm{Fe}^{0}$ remediation literature (Reardon 1995; Khan et al. 2000; Furukawa et al. 2002). Moreover, $\mathrm{Fe}^{0}$ oxidation by Eq. 8 produces iron oxides and hydroxides (Eq. 10) which form a multi-layered oxide scale on $\mathrm{Fe}^{0}$ or in its vicinity (Sun et al. 2016). As a rule, the oxide scale is electronic non-conductive, rendering (quantitative) contaminant reduction after Eq. 11 simply impossible (Ghauch 2015; Noubactep 2015). It should be recalled that all models rationalizing the occurrence of Eq. 11 despite the presence of the oxide scale were proven faulty (Odziemkowski 2009; Noubactep 2016a). It is, therefore, surprising that contaminant reduction at the surface of $\mathrm{Fe}^{0}$ has survived until the present day (Fu et al. 2014; Guan et al. 2015; Naidu and Birke 2015; Statham et al. 2016; Zou et al. 2016). The consideration of the kinetics of Eq. 8 and Eq. 11 excellently demonstrates the fallacy of the reducing $\mathrm{Fe}^{0}$, theory (Noubactep 2015, 2016a). 


\section{Kinetics of contaminant removal in $\mathrm{Fe}^{\mathbf{0}} / \mathrm{H}_{2} \mathrm{O}$ systems}

It is established that (1) the interactions between $\mathrm{Fe}^{0}$ and the oxide scale are not galvanic ones and (2) contaminant reduction in $\mathrm{Fe}^{0} / \mathrm{H}_{2} \mathrm{O}$ systems is a chemical reaction (Ghauch 2015; Noubactep 2015; Gheju et al. 2016; Sun et al. 2016). Galvanic interactions occur when electrically conducting phases (e.g., $\mathrm{Fe}^{0}$ and $\mathrm{Cu}^{0}$ or $\mathrm{Fe}^{0}$ and $\mathrm{Fe}_{3} \mathrm{O}_{4}$ ) are in contact and are present in an electrolyte. In an $\mathrm{Fe}^{0} / \mathrm{H}_{2} \mathrm{O}$ system, $\mathrm{H}_{2} \mathrm{O}$ reduction is the sole cathodic reaction that is likely to be quantitative under environmental conditions (Fig. 1) (Ghauch 2015; Noubactep 2015; Sun et al. 2016). The inherent existence of an $\mathrm{Fe}^{0}$ \%oxide interface implies time-dependant changes of the rates of $\mathrm{Fe}^{0}$ oxidative dissolution and $\mathrm{H}_{2} \mathrm{O}$ reduction (Dutrizac and MacDonald 1973; Mehta and Murr 1983; Holmes and Crundwell 1995; Sarr 2001; Ndé-Tchoupé et al. 2015; Tepong-Tsindé et al. 2015a). To fully describe the process of contaminant removal in $\mathrm{Fe}^{0} / \mathrm{H}_{2} \mathrm{O}$ systems, the kinetics of the electrode processes must be considered (Holmes and Crundwell 1995). In other words, the law of $\mathrm{Fe}^{\mathrm{II}}$ generation should be established. This approximatively corresponds to the rate of aqueous iron corrosion that has been traditionally expressed as the mass loss (per unit of surface area) per unit of time (Nesic 2007 and refs. cited therein). An alternative expression is the decrease in $\mathrm{Fe}^{0}$ thickness or the increase of the thickness of the oxide scale per unit of time (Noubactep 2016a). In the remediation research, however, the initial formation and the further transformation of the oxide scale have to be considered as well.

The kinetics of sustained $\mathrm{Fe}^{0}$ oxidative dissolution involve a series of stages comprising: (1) the $\mathrm{H}_{2} \mathrm{O}$ adsorption onto the $\mathrm{Fe}^{0}$ surface; (2) the formation of an oxide nucleus and (3) the increase in the thickness of the oxide scale. Once the oxide scale has formed over the whole surface, its growth occurs through solid-state diffusion processes within the scale (Griffin 1984; Gan and Orazem 1987; Sikora and Macdonald 2000; Nesic 2007; Lazzari 2008). The oxide scale on $\mathrm{Fe}^{0}$ is non-protective in essence; it detaches due to the compressive stresses which originate from differences in the crystal structures of metallic iron and its oxides (Noubactep 2010c; Lazzari 2008). As a consequence, the $\mathrm{Fe}^{0}$ surface is continually exposed to water and the oxidation rate can be considered constant. Thus, the oxide scale growth is linear and the generation of $\mathrm{Fe}^{\mathrm{II}}$ species can be given by an equation of the following type:

$\left[\mathrm{Fe}^{2+}\right]=k_{\text {iron }} \times t$,

where $t$ is the time and $k_{\text {iron }}$ (Noubactep 2016c) is a constant of the used metal (apparent rate constant of iron corrosion).

Giving the kinetics of iron corrosion by relations similar to Eq. 12 is certainly an oversimplification. A similar reasoning may yield the concentration of generated $\mathrm{H}_{2}$ (Eq. 8). For example, while considering the $\mathrm{H}_{2}$ entrapment rate by the iron granules (Sievert's law), the apparent corrosion rate of $\mathrm{Fe}^{0}$ materials could be characterized by monitoring $\mathrm{H}_{2}$ evolution $\left(\mathrm{V}_{\mathrm{H}}\right)$ in sealed cells (Reardon 1995, 2005). These results recall the importance of kinetic considerations and point out the following. Although $\mathrm{Fe}^{0}$ is a class of material from a thermodynamic view $\left(E^{0}=-0.44 \mathrm{~V}\right)$, it should be considered that each $\mathrm{Fe}^{0}$ material is subject to its own unique corrosion process (intrinsic reactivity). Composite iron matrix, iron nails, iron fillings, steel wool and sponge iron and other materials

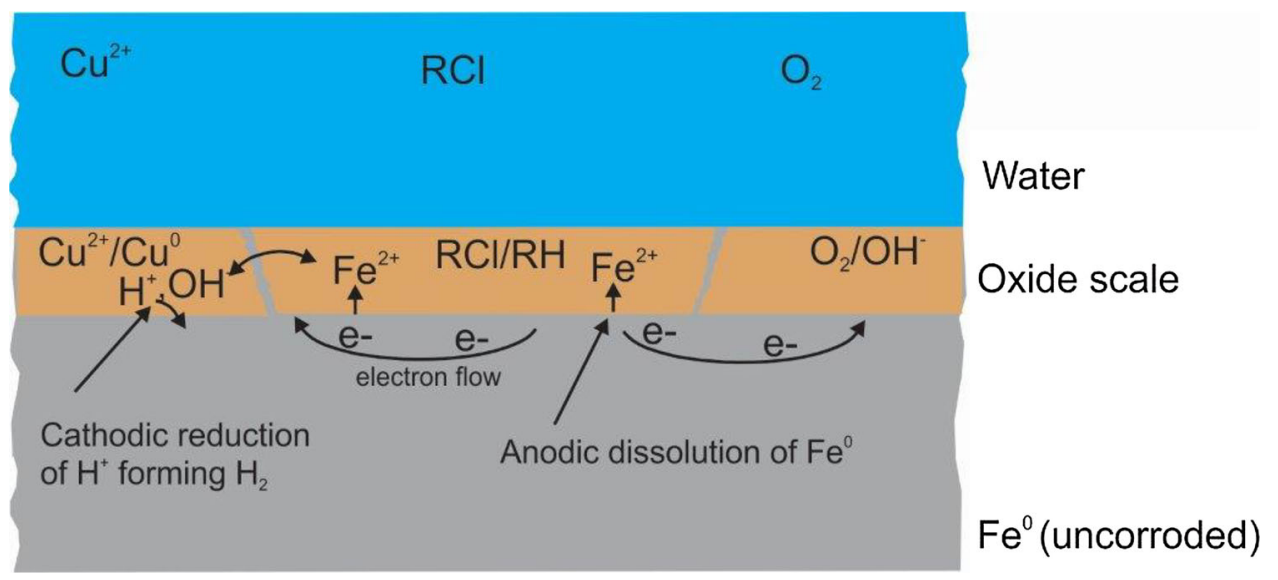

Fig. 1 The $\mathrm{Fe}^{0} / \mathrm{H}_{2} \mathrm{O}$ system labeling key features relevant for contaminant (e.g., $\mathrm{Cu}^{2+}, \mathrm{O}_{2}$ and $\mathrm{RCl}$ ) removal. Corrosion begins at a location where $\mathrm{Fe}^{2+}$ is generated (anode). $\mathrm{Fe}^{2+}$ goes into the aqueous solution and two electrons, left behind migrate to another location (cathode) where they are taken up by $\mathrm{H}^{+}$from water dissociation. The resulting hydroxide ions $\left(\mathrm{OH}^{-}\right)$react with the $\mathrm{Fe}^{2+}$ to initially form hydrous iron oxides that precipitate as $\mathrm{Fe}(\mathrm{OH})_{2}$. Depending on the environmental conditions $\mathrm{Fe}(\mathrm{OH})_{2}$ is oxidized and transformed to various $\mathrm{Fe}^{\mathrm{II}} / \mathrm{Fe}^{\mathrm{III}}$ oxides that form the oxide scale. The oxide scale impairs quantitative contaminant transfer to the $\mathrm{Fe}^{0}$ surface. Reproduced with permission of Atlas of Science 
have been widely tested and used in $\mathrm{Fe}^{0}$ filtration systems (Li et al. 2011; Allred 2012; Neumann et al. 2013 Xu et al. 2013; Allred and Racharaks 2014; Allred and Tost 2014; Ju et al. 2015a, b, c). Each tested material has its own benefits but there is still nothing like a characteristic material class, e.g., cast iron fillings perform better than iron nails for a given application. The material selected for each application needs to have the necessary chemical (and mechanical) properties to fulfill the intended function of the installation.

The typical relationship giving the kinetics of contaminant $(X)$ reduction by $\mathrm{Fe}^{\mathrm{II}}$ species is well known to geoscientist (e.g., pyrite oxidation) (Schwertmann 1991; Eggleston et al. 1996; Cornell and Schwertmann 2003; Duckworth and Martin 2004) and is given by Eq. 13. Herein, $\mathrm{m}$ and $\mathrm{n}$ are constants with ' $n+m$ ' being the order or reaction (reduction by $\mathrm{Fe}^{2+}$ ).

$d\left(\mathrm{Fe}^{\mathrm{II}}\right) / \mathrm{d} t=-k \times\left[\mathrm{Fe}^{2+}\right]^{m} \times[X]^{n}$.

Until now, $k_{\text {iron }}$ has not been determined or was determined independently from contaminant reduction (Reardon 1995, 2005; Ruhl et al. 2012a). However, $\left[\mathrm{Fe}^{2}\right.$ ${ }^{+}$] in Eq. 13 (given by Eq. 12) is produced from Eq. 8 but is difficult to quantify because of the low solubility of $\mathrm{Fe}$ in the neutral $\mathrm{pH}$ range. The main sources of electrons for any contaminant in an $\mathrm{Fe}^{0} / \mathrm{H}_{2} \mathrm{O}$ system are $\mathrm{H}_{2}$ and $\mathrm{Fe}^{\mathrm{II}}$ species (indirect reduction) (Jiao et al. 2009; Ghauch et al. 2010, 2011; Gheju and Balcu 2011; Gheju et al. 2016). Accordingly, properly modeling the kinetic of any reductive transformation in $\mathrm{Fe}^{0} / \mathrm{H}_{2} \mathrm{O}$ systems depends on the accurate characterization of the kinetics of the production of $\mathrm{Fe}^{2+}$ and $\mathrm{H}^{+}$or the determination of the kinetics of $\mathrm{Fe}^{0}$ corrosion by water (Eq. 8) (Noubactep 2016a, b).

\section{Iron mass balance}

Scientists have been also driven deeply into confusion because of the lack of mass balance for iron. The mass balance of contaminants has been done while considering that non-recovered original species is chemically reduced (Lee et al. 2004; Noubactep 2007; Ghauch 2015). In this manner, the amount of contaminant certainly enmeshed in the matrix of the oxide scale (co-precipitation) is considered chemically reduced (Noubactep 2007, 2008). Considering the mass balance of iron would have evidenced the importance of adsorption and co-precipitation that are still mostly just considered as other reaction paths beside reductive transformations (degradation or precipitation) (Chen et al. 2013; Obiri-Nyarko et al. 2014; Guan et al. 2015).

Contaminants are removed in $\mathrm{Fe}^{0} / \mathrm{H}_{2} \mathrm{O}$ systems by a synergy between adsorption, co-precipitation and size- exclusion. Contaminant chemical transformation (if applicable) is mediated by iron corrosion products (e.g., $\mathrm{Fe}^{\mathrm{II}}$, $\mathrm{Fe}^{\mathrm{III}}, \mathrm{Fe}_{3} \mathrm{O}_{4}$ and/or $\mathrm{H}_{2}$ ) but even reduced species (e.g., reaction products) must be removed to a level below the maximum contaminant level (MCL) allowed. In another phrase, the mechanisms of contaminant removal in $\mathrm{Fe}^{0}$ / $\mathrm{H}_{2} \mathrm{O}$ systems are known. The extent of individual mechanisms varies with operational parameters (e.g., amount of $\mathrm{Fe}^{0}, \mathrm{Fe}^{0}$ intrinsic reactivity, residence time, age of the $\mathrm{Fe}^{0}$ filters). Despite this evidence, the number of even recent publications investigating the mechanism of contaminant removal in $\mathrm{Fe}^{0} / \mathrm{H}_{2} \mathrm{O}$ systems is large (Guan et al. 2015 and ref. cited therein) and $\mathrm{Fe}^{0}$ is still cited as an environmental reducing agent (Zou et al. 2016).

\section{The suitability of nano-scale $\mathrm{Fe}^{\mathrm{0}}$ materials}

The relationship between the particle diameter $(d)$ and the specific surface area (SSA) helps to understand the suitability of nano $\mathrm{Fe}^{0}$. Per definition, the SSA is the surface divided by the mass. Assuming a spherical geometry, the surface is $\pi \times d^{2}$ and the mass is $\rho / 6 \times \rho \times d^{3}(\rho=$ density). Thus,

$\mathrm{SSA}=6 / \rho \times d$

For two different particle sizes $d_{1}$ and $d_{2}, d_{2}=n \times d_{1}$, $\mathrm{SSA}_{1} / \mathrm{SSA}_{2}=d_{2} / d_{1}=n \times d_{1} / d_{1}=n$. If $d_{2}=2 \times d_{1}, \mathrm{SSA}_{1} /$ $\mathrm{SSA}_{2}=2$. This means that halving the particle size doubles the surface area. In other words, using smaller particles increases the area available for contaminant accumulation (adsorption) and subsequent reduction (if applicable). However, decreasing the particle size is coupled with rapid production of corrosion products and, thus, short service life for the $\mathrm{Fe}^{0}$ materials (Gillham 2003; Crane and Scott 2012; Noubactep et al. 2012a). Moreover, because small particles react very rapidly, particle cementation is observed within a relative short time (Crane and Scott 2012; Noubactep et al. 2012a). Although there are other explanations for particle agglomeration, expansive iron corrosion is the first one and implies that dispersion of nano $\mathrm{Fe}^{0}$ is a pre-requisite for its application (Crane and Scott 2012; Noubactep et al. 2012a). Coming back to $\mu \mathrm{m}$ and $\mathrm{mm}$ sized particles, the slowness of involved processes has delayed the universal acceptance of the evidence that admixing $\mathrm{Fe}^{0}$ and non-expansive aggregate (e.g., gravel, pumice, sand) are equally a pre-requisite for sustainability (Miyajima 2012; Miyajima and Noubactep 2012; Caré et al. 2013; Noubactep 2013d). It is understood that gelatinous iron hydroxides also cement particles of added aggregates, particularly under oxic conditions. This evidence makes porous materials (composite iron matrix, sponge iron) potential better materials for sustainable $\mathrm{Fe}^{0}$ 
filters (Rahman et al. 2013; Li et al. 2011; Neumann et al. 2013; Xu et al. 2013).

\section{Adsorption capacity of $\mathrm{Fe}^{\mathrm{o}}$}

The $\mathrm{Fe}^{0}$ literature is full of partly tabulated values of the adsorption/reduction/removal capacity (e.g., $\mathrm{mg} \mathrm{g}^{-1}$ ) of $\mathrm{Fe}^{0}$ for individual contaminants (Johnson et al. 1996; Richardson and Nicklow 2002; McGeough et al. 2007; Sleiman et al. 2016). However, this parameter is non-appropriate because the used $\mathrm{Fe}^{0}$ mass says nothing about the amount of in situ generated (1) reducing agents $\left(\mathrm{Fe}^{\mathrm{II}}, \mathrm{H}_{2}\right)$ and/or (2) contaminant collectors (iron oxides) during the experiment/application. The removal capacity (sometimes termed as 'saturation') is a parameter borrowed from adsorption literature (adsorptive removal). However, in the adsorption context, the adsorptive surface (SSA) is available at the start of the experiment $\left(t_{0}=0\right)$ and the experiments are stopped at equilibrium ( $\left.t_{\infty}=t_{\text {equilibrium }}\right)$. Depending on the size and the porosity of the adsorbent, the equilibrium can be achieved within some hours. In the context of $\mathrm{Fe}^{0}$ remediation, an initial phase of increased contaminant removal is related to several processes including (1) $\mathrm{Fe}^{0}$ oxidative dissolution and (ii) precipitation of iron oxides upon local sursaturation. In particular, a slower removal kinetic following an initial rapid uptake is likely due to changes in the kinetic of $\mathrm{Fe}^{0}$ dissolution (Alamilla et al. 2009; Noubactep 2016a). This stage is at best a pseudo-equilibrium and is only indirectly coupled to an adsorption process as co-precipitation also occur and is more difficult to quantify (Crawford et al. 1993a, b).

\section{Designing $\mathrm{Fe}^{0}$ filters from laboratory data}

Efforts to develop comprehensive, cost-effective and rapid approaches for selecting media for water treatment in packed-bed filters use (1) batch laboratory tests, (2) labscale continuous flow column tests and (3) pilot-scale tests (Crittenden et al. 1986, 1987, 1991; Johnson et al. 1996; Richardson and Nicklow 2002; Westerhoff et al. 2005, 2006; Moraci and Calabrò 2010; Ndé-Tchoupé et al. 2015; Tepong-Tsindé et al. 2015a, b; Moraci et al. 2016). Such tests have been widely used to evaluate removal efficiency, robustness, operational benefits and cost effectiveness of inert adsorbents and $\mathrm{Fe}^{0}$ materials as well (Morrison et al. 2002; Westerhoff and James 2003; Morrison et al. 2006). As a rule, batch tests provided limited benefit when compared against continuous flow rapid small-scale column tests (RSSCTs) to evaluate contaminant removal capability by tested media (Westerhoff et al. 2006). Moreover, for inert adsorbents, breakthrough curves corresponded well between lab-scale RSSCT and fieldbased pilot scale, suggesting that RSSCTs offer a time- saving approach for adsorptive media selection (Crittenden et al. 1991; Westerhoff et al. 2005, 2006).

The disadvantages of pilot testing (PT) are summarized by Westerhoff et al. (2006) as follows: it is time consuming (6-8 months) and costly to construct and operate. The advantages of RSSCTs are: (1) short operation time (i.e., few weeks), limited amount of materials (i.e., some grams versus kilograms in PT) and limited amount of water (i.e., few liters versus hundreds of liters for PT). The RSSCTs approach, if reliable, would be an excellent approach to test/verify the suitability of $\mathrm{Fe}^{0}$ material for site-specific application. Unfortunately, $\mathrm{Fe}^{0}$ corrodes with a different kinetics in the time scale in question (weeks vs. years) (Alamilla et al. 2009; Noubactep 2016a). This reason alone disqualifies testing $\mathrm{Fe}^{0}$ materials by RSSCTs. Another fundamental reason against RSSCTs is that they use smaller particle sizes $\left(\mu \mathrm{m} \mathrm{Fe}{ }^{0}\right)$ of the materials. Because generated iron hydoxides and oxides occupy the same space in PT and RSSCT (Domga et al. 2015), RSSCT would clog very soon and this clogging behavior is not transferable to field situations $\left(\mathrm{mm} \mathrm{Fe}^{0}\right)$. The last fundamental flaw mediated by RSSCTs is the typically used accelerated water flow velocities. This operation increases the contaminant flux in the filter but does not (significantly) impact the kinetics of iron corrosion and, thus, the rate of production of contaminant collectors.

As summarized, there is actually no established intelligent tool to shorten the experimental duration of $\mathrm{Fe}^{0}$ testing while still obtaining reliable results. On the contrary, available discrepancies in the literature have been widely explained after purposefully lengthening the duration of batch experiments from some hours to some weeks (up to 16 weeks or 120 days) while working under quiescent conditions (Noubactep et al. 2003, 2005a, 2006, 2009a). Moreover, inert (e.g., sand) and/or reactive additives (e.g., $\mathrm{FeS}_{2}, \mathrm{MnO}_{2}$ ) have been demonstrated to sustain the efficiency of the $\mathrm{Fe}^{0} / \mathrm{H}_{2} \mathrm{O}$ system primarily by avoiding material compaction and increasing the adsorptive surface by in situ coating of the surface of the additives (Noubactep et al. 2005a; Ghauch et al. 2010, 2011; Noubactep 2013d; Gheju et al. 2016).

Tools to gain reliable design results from column studies were recently presented ( $\mathrm{Li}$ et al. 2011; Allred 2012; Btatkeu-K et al. 2013, 2014; Miyajima and Noubactep 2015; Phukan 2015; Phukan et al. 2015; Btatkeu-K. et al. 2016; Phukan et al. 2016). In this context, the differential adsorptive behavior of methylene blue onto sand and iron oxides (Mitchell et al. 1955; Saha et al. 2011) is used to follow the extent of in situ coating of sand in $\mathrm{Fe}^{0}$ /sand filters. The shortest experiments lasted for 70 days.

The results from 'long-term' batch and column studies have recalled that one should first understand the behavior 
of $\mathrm{Fe}^{0}$ particles used in water treatment before start to develop simplified tests for the materials (Noubactep 2016a). Some simple tests have been presented (Reardon 1995, 2005; Noubactep et al. 2009a; Noubactep 2011a, 2012b; Li et al. 2016) whose adoption would accelerate the understanding of $\mathrm{Fe}^{0} / \mathrm{H}_{2} \mathrm{O}$ systems. However, properly modeling the behavior of $\mathrm{Fe}^{0}$ filters goes exclusively through the characterization of the long-term kinetics of relevant particles and field conditions ( $\mathrm{Lu}$ et al. 2016; Sun et al. 2016).

\section{$\mathrm{Fe}^{\mathrm{0}}$ as external source of $\mathrm{Fe}^{\mathrm{II}}$}

One of the first $\mathrm{Fe}^{0}$ applications for safe drinking water provision consisted in in situ producing $\mathrm{Fe}^{\mathrm{II}}$ to enhance the natural $\mathrm{Fe}^{\mathrm{II}}$ level of groundwater. This operation enabled arsenic removal by sand filtration (Khan et al. 2000; Noubactep et al. 2012b). The method generates $\mathrm{Fe}^{2+}$ by contacting groundwater with $\mathrm{Fe}^{0}\left(\mathrm{H}_{2} \mathrm{O}\right.$ oxidizes $\mathrm{Fe}^{0}$ Eq. 1). Generated $\mathrm{Fe}^{2+}$ species are reported to form hydrous ferric oxide (HFO) upon oxidation and As adsorbed on HFO is efficiently removed by a (subsequent) sand filtration (Gottinger et al. 2013; Kowalski and Søgaard, 2014; Wan et al. 2016). In other words, $\mathrm{Fe}^{0}$ is oxidized by water to certainly produce efficient As adsorbents (including HFO).

Quantitative oxidation of $\mathrm{As}^{\mathrm{III}}$ to $\mathrm{As}^{\mathrm{V}}$ has been widely assumed to rationalize the process of As removal, since As ${ }^{\mathrm{III}}$ removal by HFO is not quantitative (Leupin and Hug 2005). This simplification ignores the evidence that $\mathrm{HFO}$ and other iron precipitates are formed in situ in the presence of As. Thus, $\mathrm{As}^{\mathrm{III}}$ coprecipitation is likely to be quantitative (Crawford et al. 1993a, 1993b; Noubactep 2007, 2008). The proof that As is not quantitatively removed after any oxidation reaction is given by the quantitative removal of selenium in $\mathrm{Fe}^{0} / \mathrm{H}_{2} \mathrm{O}$ systems (CH2 M Hill, 2010; Twidwell and McCloskey 2011). It is the oxidized Se species, selenate $\left(\mathrm{Se}^{\mathrm{VI}}\right)$ which is not quantitatively removed by HFO. HFO quantitatively removed selenite $\left(\mathrm{Se}^{\mathrm{IV}}\right)$. This means that quantitative Se removal in $\mathrm{Fe}^{0} / \mathrm{H}_{2} \mathrm{O}$ systems would have been rationalized by reduction of $\mathrm{Se}^{\mathrm{VI}}$ to $\mathrm{Se}^{\mathrm{IV}}$. However, it would be absurd to consider that the $\mathrm{Fe}^{0} / \mathrm{H}_{2} \mathrm{O}$ system selectively removes certain contaminants upon oxidation (e.g., As) and others upon reduction (e.g., Se).

The reasoning in this section has shown that $\mathrm{Fe}^{0}$ has been successfully used as external source of $\mathrm{Fe}^{\mathrm{II}}$ for decontamination: $\mathrm{Fe}_{\text {(groundwater) }}^{2+}+\mathrm{Fe}_{\text {(iron corrosion) }}^{2+}$ generates enough adsorbents for contaminant removal by adsorption and co-precipitation. This knowledge co-exists in the scientific literature with the view that adding external $\mathrm{Fe}^{2+}$ sustains contaminant reduction by $\mathrm{Fe}^{0}$ (Huang et al.
2012, 2013a, b). The fallacy of this view has been largely demonstrated in previous sections. On the other hand, using $\mathrm{Fe}^{0}$ as external source of $\mathrm{Fe}^{\mathrm{II}}$ recalls that $\mathrm{Fe}^{0}$ oxidation by water (Eq. 8) is quantitative.

\section{External source of $\mathrm{Fe}^{\mathrm{II}}$ sustains $\mathrm{Fe}^{\mathrm{0}}$ efficiency}

Equation 8 can be re-written as a chemical equilibrium.

$\mathrm{Fe}^{0}+2 \mathrm{H}^{+} \Leftrightarrow \mathrm{Fe}^{2+}+\mathrm{H}_{2}$

According to LeChatelier's Principle, if $\mathrm{Fe}^{2+}$ is added to an $\mathrm{Fe}^{0} / \mathrm{H}_{2} \mathrm{O}$ system (external $\mathrm{Fe}^{\mathrm{II}}$ ), the equilibrium will be shifted to the left, meaning that less $\mathrm{Fe}^{0}$ is corroded. Therefore, the argument that external $\mathrm{Fe}^{\mathrm{II}}$ sustains contaminant reduction by $\mathrm{Fe}^{0}$ is not acceptable. Since increased contaminant removal upon addition of external $\mathrm{Fe}^{\mathrm{II}}$ has been largely documented (Huang et al. 2012, 2013a, b), this observation needs a scientific explanation.

An $\mathrm{Fe}^{0} / \mathrm{H}_{2} \mathrm{O}$ system is the home state of iron oxides (oxide scale) with adsorptive affinities to $\mathrm{Fe}^{\mathrm{II}}$ species and contaminants (Mitchell et al. 1955; Miyajima 2012; Btatkeu-K et al. 2014; Phukan 2015; Phukan et al. 2015; Btatkeu-K. et al. 2016; Phukan et al. 2016). Adsorbed Fe ${ }^{\mathrm{II}}$ (termed as structural $\mathrm{Fe}^{\mathrm{II}}$ ) is a more powerful reducing agent than dissolved $\mathrm{Fe}^{\mathrm{II}}$ (Table 1) (White and Peterson 1996; Liger et al. 1999). Accordingly, increased contaminant reduction in $\mathrm{Fe}^{0} / \mathrm{H}_{2} \mathrm{O}$ systems upon addition of external $\mathrm{Fe}^{\mathrm{II}}$ is thermodynamically funded. On the other hand, external $\mathrm{Fe}^{\mathrm{II}}$ increases the concentration of iron and the probability of precipitation (by exceeding the solubility limit). Contaminants are adsorbed onto Fe precipitates and/ or co-precipitated with the same. This process is responsible for the better efficiency of $\left(\mathrm{Fe}^{0}+\right.$ external $\left.\mathrm{Fe}^{\mathrm{II}}\right)$ systems relative to $\mathrm{Fe}^{0}$ systems.

This section has recalled that $\mathrm{Fe}^{0}$ is quantitatively oxidized by water (Eq. 1) and that the increased efficiency of $\mathrm{Fe}^{0} / \mathrm{H}_{2} \mathrm{O}$ systems upon addition of external $\mathrm{Fe}^{\mathrm{II}}$ is a proof that primary $\left(\mathrm{Fe}^{\mathrm{II}}, \mathrm{H}_{2}\right)$ and secondary (hydroxides/oxides) corrosion products are responsible for decontamination: chemical transformation and removal from the aqueous phase. In other words, $\mathrm{Fe}^{0}$ is the generator of contaminant collectors (Yao et al. 1971). This knowledge was established prior to the introduction of the $\mathrm{Fe}^{0}$ remediation technology (Tseng et al. 1984; James et al. 1992). For example, Tseng et al. (1984) used steel wool (an $\mathrm{Fe}^{0}$ material) to in situ produce iron oxides as adsorbents for the concentration ${ }^{60} \mathrm{Co}$ from sea water. In another phrase, the fact that so many publications are still discussing the mechanism of contaminant removal in $\mathrm{Fe}^{0} / \mathrm{H}_{2} \mathrm{O}$ systems is highly confusing. Remember that for the range of concentrations of natural waters, chemical reduction is rarely a 
stand-alone removal mechanism as (1) the initial concentrations are sometimes lower than the solubility limit of the oxidized species or (2) the maximum contamination level (MCL) is higher than the solubility limit of the reduced species (Ndé-Tchoupé et al. 2015). The former case means that the realized decontamination is due to meta-stability while the later demonstrates that additional efforts are needed to reach concentrations lower than the MCL. For properly designed $\mathrm{Fe}^{0} / \mathrm{H}_{2} \mathrm{O}$ systems, contaminants are removed by adsorption, coprecipitation and size-exclusion.

\section{$\mathrm{Fe}^{\mathbf{0}}$ ratio in a filter}

The differential use of $\mathrm{Fe}^{0}$ as a reducing agent (Matheson and Tratnyek 1994; Weber 1996) or a generator of contaminant collectors (Khan et al. 2000; Gottinger et al. 2013; Chaudhari et al. 2014; Kowalski and Søgaard 2014) suggests that the amount (e.g., the mass in gram) of $\mathrm{Fe}^{0}$ to be used is case specific. For example, Berg et al. (2006) reported that an Fe/As ratio of 250 is required to achieve less than $10 \mu \mathrm{g} / \mathrm{L}$ arsenic concentration. Lower $\mathrm{Fe} / \mathrm{As}$ ratios have been reported by other researches (Khan et al. 2000), but this issue is not discussed herein. While using $\mathrm{Fe}^{0}$ as a reducing agent, the $\mathrm{Fe}^{0}$ amount is deduced from the stoichiometry of the involved reaction (e.g., Eq. 11). The presentation above has recalled that using reactions similar to Eq. 11 is not acceptable. But the focus in this section is on the kinetics of iron corrosion or the question how long should the experiment last to produce the required amount of reducing agents or adsorbents (iron oxides)?

This question cannot be answered without knowledge of the rate constant of iron corrosion $\left(k_{\text {iron }}\right)$. $k_{\text {iron }}$ values relevant for the particle sizes used in $\mathrm{Fe}^{0}$ filters cannot be obtained from the open corrosion literature and are yet to be determined (Noubactep 2016a). In the absence of $k_{\text {iron }}$ values, no scientific discussion on the right $\mathrm{Fe}^{0}$ amount can be performed. This is arguably the main reason why published results are highly qualitative in nature. As an example, the community-scale $\mathrm{Fe}^{0}$ arsenic filter developed at the Indian Institute of Technology Bombay (IITB filter) uses commercial iron nails of unknown $k_{\text {iron }}$ values (Chaudhari et al. 2014). Each community filters used some $10 \mathrm{~kg}$ iron nails and should work for about 5 years. However, it is not certain that (1) various nail types will give comparable results or (2) the same iron nails at locations with very different water chemistry would work well.

Summarizing the $\mathrm{Fe}^{0}$ amount to be used cannot be addressed before a testing protocol for $\mathrm{Fe}^{0}$ materials is established. Such tests in long-term experiments ( $>1$ year) would yield classes of $k_{\text {iron }}$ values which could be used for individual applications (e.g., household filter, $\mathrm{HCO}_{3}$-rich groundwater, chloride-rich wastewaters). $k_{\text {iron }}$ values will also determine the $\mathrm{Fe}^{0}$ ratio to be used in a filter (e.g., $\mathrm{Fe}^{0}$ / sand). For example, $5 \%(\mathrm{v} / \mathrm{v})$ of a highly reactive material can be sufficient where $20 \%$ of a less reactive material would be needed.

\section{Sustainable $\mathrm{Fe}^{\mathbf{0}}$ filters}

Filters containing more than $52 \% \mathrm{Fe}^{0}$ (v/v) will clog before $\mathrm{Fe}^{0}$ is depleted (material wastage) (Noubactep et al. 2010; Caré et al. 2013). Calculations have been made for spherical particles and a compaction of 64 or $36 \%$ porosity (Noubactep and Caré 2010a, b, 2011; Caré et al. 2013; Rahman et al. 2013; Domga et al. 2015). However, it is certain that the higher the $\mathrm{Fe}^{0}$ ratio, the shorter the service life. Further calculations have shown that the optimal hybrid system concealing long-term efficiency (high $\mathrm{Fe}^{0}$ ) and long-term permeability (less $\mathrm{Fe}^{0}$ ) is $25 \% \mathrm{Fe}^{0}$ (v/v) (Miyajima 2012; Miyajima and Noubactep 2012; Btatkeu$\mathrm{K}$ et al. 2014, 2016). However, as discussed above, using just $5 \%$ of an $\mathrm{Fe}^{0}$ material could correspond to $20 \%$ of another material depending on the $k_{\text {iron }}$ value.

Sand is the most abundant admixing agent for $\mathrm{Fe}^{0}$ filters. $\mathrm{Fe}^{0} /$ sand filters should, therefore, be considered a reference system and other systems tested in comparison (Btatkeu-K et al. 2014, 2016). This approach has not been adopted and various aggregates $\left(\mathrm{Fe}_{3} \mathrm{O}_{4}\right.$, gravel, pumice, zeolite) have been positively tested (Moraci and Calabrò 2010; Huang et al. 2012; Bilardi et al. 2013a, b; Huang et al. 2013a, b). In all the cases, it should be considered that the initial system $\left(t_{0}=0\right)$ is made up of $\mathrm{Fe}^{0}$ and the used aggregate (s). With increasing operational duration $\left(t>t_{0}\right)$, the aggregates are progressively coated with iron oxides (in situ coating). This is particularly valid for inert aggregates like sand or pumice. In other words, in many systems, the whole filter probably becomes an ionic selective system, preferentially adsorbing species with high affinities to iron oxides (Phukan 2015; Phukan et al. 2015, 2016).

\section{A right wording}

The terms 'efficiency' and 'reactivity' are confusingly used in the $\mathrm{Fe}^{0}$ literature. Miyajima and Noubactep (2015) complained that these terms are mostly randomly interchanged. However, reactivity is an intrinsic property of each material while the efficiency is the expression of the reactivity under specific operational conditions.

In essence, the reactivity of an $\mathrm{Fe}^{0}$ specimen cannot be measured but just indirectly assessed by index comparable to the iodine number or the molasse number for activated carbons (Attia et al. 2008). Such an index can be the $\mathrm{H}_{2}$ volume produced for a fixed duration by a fixed $\mathrm{Fe}^{0}$ mass 
under well-defined operational conditions (Reardon 1995). No simple protocol for the characterization of the $\mathrm{Fe}^{0}$ reactivity based on $\mathrm{H}_{2}$ production has been presented. An already tested index of the $\mathrm{Fe}^{0}$ reactivity is the $\mathrm{k}_{\mathrm{EDTA}}$ value introduced by Noubactep et al. (2005b) and validated by Btatkeu-K et al. (2013). The $k_{\text {EDTA }}$ is defined as the rate constant of the dissolution of $0.1 \mathrm{~g}$ of an $\mathrm{Fe}^{0}$ specimen in $50 \mathrm{~mL}$ of a $2 \mathrm{mM}$ M EDTA solution for $96 \mathrm{~h}$ (4 days). Li et al. (2016) have recently presented a 'facile method for determining' the $\mathrm{Fe}^{0}$ reactivity.

The method of Li et al. (2016) is reported to be based on $\mathrm{Fe}^{\mathrm{III}} / \mathrm{Fe}^{0}$ redox reaction (Eq. 7, Table 1) which is kinetically rapid, and has a simple stoichiometry, and easy-toassay reaction products. The experimental protocol implied mixing $\mathrm{Fe}^{0}$ sample with concentrated $\mathrm{Fe}^{\mathrm{III}}$ solution $\left(\leq 3.0 \mathrm{~g} \mathrm{~L}^{-1}\right)$ for up to $4 \mathrm{~h}$. The tested $\mathrm{Fe}^{0}$ specimen is characterized by both (1) the extent of iron dissolution (final total dissolved iron), and (2) the observed dissolution rate constants (intrinsic reactivity). The used experimental duration (just $4 \mathrm{~h}$ ) can be regarded as too short to address the complexity of processes occurring in $\mathrm{Fe}^{0} / \mathrm{H}_{2} \mathrm{O}$ systems (Btatkeu-K et al. 2016; Noubactep 2016a). However, this very recent paper by $\mathrm{Li}$ et al. (2016) is recommended for the state-of-the-art knowledge on quality assurance and quality control for $\mathrm{Fe}^{0}$ materials used in water treatment. In particular, it recalls (1) the diversity of $\mathrm{Fe}^{0}$ materials (e.g., chemical composition, origin, size), (2) that the success of $\mathrm{Fe}^{0}$ in any application depends largely on the material quality, and (3) that reliable methods for $\mathrm{Fe}^{0}$ selection (quality assurance) are urgently needed (Richardson and Nicklow 2002; Btatkeu-K et al. 2016). Table 4 summarizes some uses of $\mathrm{Fe}^{0}$ materials implying aqueous iron corrosion. It is obvious from the diversity of applications that available expertise should be exploited for the $\mathrm{Fe}^{0}$ remediation technology.

\section{The effects of co-solutes on the efficiency of $\mathrm{Fe}^{0} / \mathrm{H}_{2} \mathrm{O}$ systems}

More than thirty variables have been experimentally shown to significantly affect the efficiency of $\mathrm{Fe}^{0} / \mathrm{H}_{2} \mathrm{O}$ systems for water treatment (Henderson and Demond 2007; Xie and Shang 2007; Noubactep et al. 2009a; Comba et al. 2011; Gheju 2011; Obiri-Nyarko et al. 2014; Guan et al. 2015; Sun et al. 2016; Naseri et al. 2017). Related experiments were performed under a variety of conditions (Noubactep et al. 2009a; Li et al. 2016; Sun et al. 2016). This makes comparisons and correlation of achieved results difficult. An analysis of the fundamental processes yielding decontamination, together with some recently achieved results (Btatkeu-K et al. 2016), brings out a number of important considerations which greatly simplify studies of the $\mathrm{Fe}^{0} / \mathrm{H}_{2} \mathrm{O}$ system. The effects of common operational parameters (e.g.,
$\mathrm{Fe}^{0}$ size, $\mathrm{Fe}^{0}$ type, $\mathrm{Fe}^{0}$ pre-treatment, nature and concentration of contaminants, $\mathrm{pH}$ value, presence of dissolved $\mathrm{O}_{2}$, reaction temperature, reaction time) can only be systematically investigated, on a case-by-case basis. On the contrary, the effects of environmental ligands (e.g., bicarbonate, chloride, humic substances, phosphate, sulfate) and other common ions (e.g., chlorate, fluoride, nitrate, nitrite) can be investigated in a way that more transferable results are achieved. This approach is necessary as some contaminants (mostly nitrate and phosphate) are co-solutes in many situations (Chirukuri and Atmakuru 2015).

If the concentration of all species was typically given in moles per litre $\left(\mathrm{mol} \mathrm{L}^{-1}\right)$, it would be practically easier to (1) correlate data obtained from different $\mathrm{Fe}^{0} / \mathrm{H}_{2} \mathrm{O}$ systems using the same $\mathrm{Fe}^{0}$ sample or (2) discuss data obtained from $\mathrm{Fe}^{0} / \mathrm{H}_{2} \mathrm{O}$ systems using different $\mathrm{Fe}^{0}$ samples. For instance, data for the impact of phosphate $\left(\mathrm{PO}_{4}^{3-}\right)$ could be grouped according to the tested $\mathrm{PO}_{4}$-concentration ranges (e.g., $0-50 \mu \mathrm{M}, 50-100 \mu \mathrm{M}, 100-250 \mu \mathrm{M} . .$. ), whether $\mathrm{PO}_{4}^{3-}$ is a contaminant or a co-solute. This approach would enable a better discussion of the progress of iron corrosion as impacted by the available amount of phosphate (Noubactep et al. 2012a). If future investigations follow this approach, a database will soon be available to enable the identification of sets of conditions, within which comparable effects of individual co-solutes on the rate of corrosion are achieved. It can be emphasized that the failure to distinguish between these ranges within which different factors are controlling $\mathrm{Fe}^{0}$ dissolution is one of the fundamental reasons why controversial results have so frequently been drawn in characterizing the effects of operational parameters on the efficiency of $\mathrm{Fe}^{0} / \mathrm{H}_{2} \mathrm{O}$ systems (Noubactep 2015).

\section{Discussion}

\section{Decontamination mechanism}

Metallic iron $\left(\mathrm{Fe}^{0}\right)$ is now established as a key material for environmental remediation, industrial wastewater treatment and safe drinking water provision (Hussam and Munir 2007; Comba et al. 2011; Gheju 2011; Gottinger et al. 2013; Noubactep 2013a, b; Kowalski and Søgaard 2014; Ghauch 2015; Guan et al. 2015; Naidu and Birke 2015; Noubactep 2015; Zou et al. 2016). Upon well design, $\mathrm{Fe}^{0}$ filters are able to eliminate and/or transform a wide array of biological and chemical species. Relevant species included chlorinated aliphatic hydrocarbons, azo-dyes, bacteria, carbon disulfides, chlorinated aromatics, heavy metals nitro-aromatics and radionuclides (Johnson et al. 1996; Richardson and Nicklow 2002; Henderson and Demond 2007; McGeough et al. 2007; Fu et al. 2014; Obiri-Nyarko 
Table 4 The various use of $\mathrm{Fe}^{0}$ materials

\begin{tabular}{lll}
\hline Application & $\mathrm{Fe}^{0}$ function & References \\
\hline Cementation & Recovery of relevant metal ions by surface precipitation & Alamilla et al (2009); Allred (2012) \\
Fluid disinfection & Affinity of selected microbes for $\mathrm{Fe}^{0}$ materials (e.g., steel) & Allred and Racharaks (2014) \\
Food packaging & Protecting oxygen-sensitive foods, fixing humidity & Allred and Tost (2014); Antia (2010) \\
Liquid clarification & Separation of solid particles from liquid media & Attia et al (2008); Baker (1934) \\
Magnetic separation & Attraction of magnetic active contaminants (in a magnetic field) & Bartzas and Komnitsas (2010); Baylis (1926) \\
$\mathrm{O}_{2}$ scavenging & Lowering the concentration of $\mathrm{O}_{2}$, creating anoxic conditions & Berg et al. (2006); Bi et al. (2009) \\
Organic synthesis & Catalytic or reducing & Bilardi et al. (2013b) \\
Reduction of $\mathrm{NO}_{x}$ & Mitigation of nitrogen oxides $\left(\mathrm{NO}_{x}\right)$ emitted from combustion processes. & Bilardi et al. (2013a) \\
Water piping & Water distribution systems & Birke et al. (2015) \\
Water treatment & Removal of chemical and microbial contamination & Bischof (1877) \\
\hline
\end{tabular}

et al. 2014; Guan et al. 2015). These species are neutral, negatively or positively charged, polar or not, small or large in size, redox reactive or not. They are collectively removed from the aqueous phase by three mechanisms: (1) adsorption, (2) co-precipitation and (3) size-exclusion. Chemical reductive (and/or oxidative) transformations may occur within the system but are not mediated by the uncorroded iron (Ghauch 2015; Noubactep 2015; Gheju et al. 2016). The abundant literature on $\mathrm{Fe}^{0}$ remediation has a qualitative character because no collective effort for systematic research has been made. The knowledge that the $\mathrm{Fe}^{0} / \mathrm{H}_{2} \mathrm{O}$ system is ion selective should support both the design of future experiments and their interpretation. If this path is followed by several research groups and the results are discussed with respect to charge/size of tested contaminants, a database would be soon available to boost the optimization of $\mathrm{Fe}^{0}$ filters.

\section{Designing $\mathrm{Fe}^{\mathbf{0}}$ filters}

The evidence that $\mathrm{Fe}^{0}$ filters clog after a certain service life (Westerhoff and James 2003; Hussam and Munir 2007; Hussam 2009; Kowalski and Søgaard 2014) has been investigated independently from the knowledge that iron corrosion is a volumetric expansive process (Pilling and Bedworth 1923; Caré et al. 2008). Based on the assumption that $\mathrm{Fe}^{0}$ is a reducing agent, conventional $\mathrm{Fe}^{0}$ filters contain $100 \%$ iron in their reactive zone. Reactive zones with less $\mathrm{Fe}^{0}$ ratios were tested to investigate the extent of filter's efficiency despite ' $\mathrm{Fe}^{0}$ dilution'. Another reason for hybrid $\mathrm{Fe}^{0}$ filters (e.g., $\mathrm{Fe}^{0} /$ sand) was to save $\mathrm{Fe}^{0}$ costs (Bi et al. 2009; Ulsamer, 2011).

The proper consideration of the volumetric expansive nature of iron corrosion has demonstrated that only hybrid $\mathrm{Fe}^{0}$ filters are sustainable (Noubactep and Caré 2010b; Noubactep et al. 2010; Noubactep and Caré 2011; Bilardi et al. 2013a, b; Caré et al. 2013; Noubactep 2013d; Rahman et al. 2013). The most investigated hybrid system to date is the $\mathrm{Fe}^{0} /$ sand system; other additives include anthracite, $\mathrm{Fe}_{3} \mathrm{O}_{4}, \mathrm{MnO}_{2}$ and pumice (Moraci and Calabrò 2010; Bilardi et al. 2013a, b; Ruhl et al. 2012b; Btatkeu-K et al. 2014). Ideally each additive should be tested using the $\mathrm{Fe}^{0} /$ sand system as reference. If this effort is not made, observations will be speculatively interpreted. It is sufficient to note that the $\mathrm{Fe}^{0} / \mathrm{Fe}_{3} \mathrm{O}_{4}$ system (Huang et al. 2012, a, b) initially combines the positively charged surface of $\mathrm{Fe}_{3} \mathrm{O}_{4}$ and in situ generation of $\mathrm{Fe}^{\mathrm{II}}$ (and $\mathrm{H} / \mathrm{H}_{2}$ ) species by corroding $\mathrm{Fe}^{0}$ to remove (and transform) contaminants. In an $\mathrm{Fe}^{0}$ /sand system, the initially negatively charged sand surface is progressively coated by a positively charged oxide scale. This implies that investigation regarding the functionality of $\mathrm{Fe}^{0} / \mathrm{H}_{2} \mathrm{O}$ systems should last for several months. As discussed herein, tools to shorten the experimental duration would only make sense when a profound understanding of the system is achieved.

\section{Characterization of $\mathrm{Fe}^{\mathrm{0}}$ reactivity}

$\mathrm{Fe}^{0}$ samples for water treatment and environmental remediation are conventionally characterized for their elemental composition using for example atomic adsorption spectroscopy (AAS), inductively coupled plasma mass spectrometry (ICP MS) or X-ray fluorescence (XRF). The samples are also characterized using BET- $\mathrm{N}_{2}$ adsorption, scanning electron microscope (SEM) and X-ray diffraction (XRD). The results have demonstrated that $\mathrm{Fe}^{0}$ materials used for environmental remediation widely varied in their elemental composition but no correlation with the efficiency of related systems could be established (Richardson and Nicklow 2002; Miehr et al. 2004; Noubactep et al. 2005a; Btatkeu-K et al. 2013; Birke et al. 2015; Li et al. 2016).

$\mathrm{Fe}^{0}$ materials also vary in shape, size, surface area, and are dissimilar in reactivity (Richardson and Nicklow 2002; $\mathrm{Li}$ et al. 2016). $\mathrm{Fe}^{0}$ materials are of various types (e.g., cast iron, direct reduced iron), alloyed to a large number of 
elements (e.g., C, Cr, Mn, Ni, S, Si or Ti) and are sometimes embedded in complex composites (e.g., with activated carbon, bentonite, clay, membrane and $\mathrm{MnO}_{2}$ ) (Ghauch et al. 2010; Zou, et al. 2010; Ghauch et al. 2011). These $\mathrm{Fe}^{0}$ materials necessarily depict disparities in their intrinsic reactivity but correlating the reactivity to any material characteristic properties, including the nature of alloyed elements, was proven an impossible task (Richardson and Nicklow 2002; Miehr et al. 2004; Noubactep et al. 2009a; Btatkeu-K et al. 2013; Birke et al. 2015; $\mathrm{Li}$ et al. 2016). Disparities in $\mathrm{Fe}^{0}$ reactivity were also documented as resulting from differences in synthetic routes (e.g., gas condensation, $\mathrm{H}_{2}$ reduction and sodium borohydride reduction) (Richardson and Nicklow 2002; Li et al. 2016).

The presentation above clearly demonstrates that characterizing the reactivity of $\mathrm{Fe}^{0}$ materials for water treatment is still a challenge to the scientific community. Past and current efforts have failed to properly consider the specificities of $\mathrm{Fe}^{0}$ materials, in particular their comparatively small size and the paucity of corrosion rate constants applicable to $\mathrm{Fe}^{0}$ filters (Richardson and Nicklow 2002; Noubactep 2010b, 2015; Li et al. 2016). This conclusion clearly shows that the 'heart' of the $\mathrm{Fe}^{0}$ technology has not been properly considered. It is, therefore, not surprising that a circular reasoning is established within the $\mathrm{Fe}^{0}$ research community. This circular reasoning is termed herein as a Valley of Confusion. It is now the time to collectively leave this valley.

\section{Undermining the scientific method}

Jarrard (2001) summarized some guidance for scientists in an online book on "the structure of science", its methodologies and logic. Richard D. Jarrard argued that many scientists may agree on the following elements of successful scientific method: "Facts are collected by carefully controlled experiments. Based on these facts, verifiable hypotheses are proposed, objectively tested by further experiments, and thereby proven or discarded." Herein, 'facts' and 'observations' can be randomly interchanged. This section recalls that the fundamental elements of the scientific method have been undermined in the $\mathrm{Fe}^{0}$ remediation research. The research started with the observation that chlorinated compounds were chemically reduced in a steel canister. This tangible observation (a fact) yielded to hypothesis that $\mathrm{Fe}^{0}$ was the reducing agent (an hypothesis) (Matheson and Tratnyek 1994). Unfortunately, the hypothesis by Matheson and Tratnyek (1994) was considered a fact by Weber (1996) and validated as such (Ebelle et al. 2016; Noubactep 2016d).

To understand what went wrong with research on $\mathrm{Fe}^{0}$ filters, the following text from Jarrard (2001) will be reproduced: "A law is an explanation in which we have the greatest confidence, based on a long track record of confirmations. A theory, for most scientists, denotes an explanation that has been confirmed sufficiently to be generally accepted, but which is less firmly established than a law. An axiom is a concept that is accepted without proof, perhaps because it is obvious or universally accepted (e.g., time, causality) or perhaps to investigate its implications. A hypothesis is an idea that is still in the process of active testing; it may or may not be correct. Models are mathematical or conceptual hypotheses that provide useful perspectives in spite of recognized oversimplification. Whereas laws and theories are relatively static, hypothesis formation, testing, and evaluation are the dynamic life of science." It appears that the evidence that $\mathrm{Fe}^{0}$ is a reducing agent $\left(E^{0}=-0.44 \mathrm{~V}\right.$ for the couple $\mathrm{Fe}^{\mathrm{II}} / \mathrm{Fe}^{0}$, Table 1$)$ has been considered an axiom (accepted without proof) within the $\mathrm{Fe}^{0}$ environmental research community. This is a plausible explanation why, despite one decade of severe refutation (Noubactep 2006, 2007, 2008, 2009a, b, c, 2010a, 2011c, 2015, 2016a, c, d), the theory that $\mathrm{Fe}^{0}$ is an environmental reducing agent has survived (Richardson and Nicklow 2002; Fu et al. 2014; Guan et al. 2015; Zou et al. 2016). However, accepting this theory is refuting the law that under environmental conditions, the $\mathrm{Fe}^{0}$ surface is shielded by a non-conductive scale, making any quantitative electron transfer impossible. In other words, the scientific method has been falsified for the $\mathrm{Fe}^{0}$ / $\mathrm{H}_{2} \mathrm{O}$ system by considering $\mathrm{Fe}^{0}$ an own reducing agent. This mistake is incorporated in the majority of available models and theories (Fu et al. 2014; Obiri-Nyarko et al. 2014; Guan et al. 2015; Moraci et al. 2016).

Actually, the major reason for undermined scientific method is identified but this is not sufficient to justify why a fallacy has survived for two decades. In particular, if observations were collected and reproduced under controlled conditions and the initial hypotheses verified, the validity of the theory that $\mathrm{Fe}^{0}$ is a reducing agent under environmental conditions would have been refuted. Unfortunately, attempts to independently reproduce experimental results are very scarce in the $\mathrm{Fe}^{0}$ literature (Noubactep 2015). This means that $\mathrm{Fe}^{0}$ was considered a class of material and results obtained with various $\mathrm{Fe}^{0}$ materials compared to each other (Richardson and Nicklow 2002; Miehr et al. 2004; Birke et al. 2015; Li et al. 2016). Such an approach always results in qualitative results. It is not surprising that despite two decades of intensive research, the $\mathrm{Fe}^{0}$ remediation technology is still in its infancy (Noubactep 2015, 2016a, c).

Finally, the scientific method has been undermined by a lack of critical evaluation of the available literature on the $\mathrm{Fe}^{0} / \mathrm{H}_{2} \mathrm{O}$ system at the introduction of the technology and during the past two decades. Three examples will be given for illustration. 
Example 1 Cast iron pipes have been largely used for water distribution (Baylis 1926; Laskowski et al. 2015). It is established that iron corrosion in cast iron pipes: (1) causes increased turbidity, (2) impairs effectiveness of disinfectants due to their reaction with $\mathrm{Fe}^{\mathrm{II}}$ (Kiéné et al. 1998; Zhang et al. 2008; Liu et al. 2014), and (3) causes increased roughness of the pipe's interior as a result of a corrosion scale that grows at the $\mathrm{Fe}^{0}$ surface. Despite this evidence, the $\mathrm{Fe}^{0}$ remediation community has overseen that 'increased turbidity' and 'scale growth' are the main cause of porosity loss in their filters (Noubactep 2013d).

Example 2 The reduction of nitrobenzene in the presence of $\mathrm{Fe}^{0}$ corresponds to the synthesis of aniline as introduced in 1854 by Béchamp (Popat and Padhiyar 2013; and refs. cited therein). However, the Béchamp process is only quantitative in acidic solutions (e.g., $\mathrm{HCl}$ ). The Béchamp process is the oldest commercial process for preparation of amines (Popat and Padhiyar 2013). The quality of obtained amines is sensitive to operational parameters such as physical state of iron, $\mathrm{pH}$ value, type of acid used and agitation speed (Popat and Padhiyar 2013; Hindle et al. 2006; Dong et al. 2010; Le et al. 2011). Despite this century old knowledge, the quantitative reduction of nitrobenzene by $\mathrm{Fe}^{0}$ has been independently discussed (Hung et al. 2000; Hindle et al. 2006; Huang and Zhang 2006). Unfortunately, this discussion has not addressed the reason why nitrobenzene reduction should be quantitative at neutral $\mathrm{pH}$ values.

Example 3 Warning of some scientists (LipczynskaKochany et al. 1994; Farrell et al. 2001; Lavine et al. 2001; Noubactep 2006; Jiao et al. 2009) about the stability of the theory that $\mathrm{Fe}^{0}$ is an environmental reducing agent has been collectively ignored (Richardson and Nicklow 2002; Fu et al. 2014; Guan et al. 2015; Zou et al. 2016). Moreover, the alternative theory that $\mathrm{Fe}^{0}$ is a generator of reducing agents and iron oxides (Noubactep 2006, 2007, 2008) was equally refuted (Kang and Choi 2009; Tratnyek and Salter 2010), incompletely considered (Chen et al. 2013; Guan et al. 2015) or simply ignored (Fu et al. 2014; Zou et al. 2016). Actually, the alternative theory has conciliated the $\mathrm{Fe}^{0}$ literature with mainstream science while using the scientific method as presented by Jarrard (2001).

\section{The way forward}

The presentation herein is a continuation of a systematic work that has been lasting for the last 10 years. The work started by the ascertainment that $\mathrm{Fe}^{0}$ should be a universal material for water treatment in deep bed filtration (Noubactep 2007, 2008, 2009a, 2010a, b, 2011a; Noubactep et al. 2009b). This ascertainment was based on, and supported by previous reports on the efficiency of $\mathrm{Fe}^{0}$ for the quantitative removal several classes of biological and chemical contaminants (Bojic et al. 2001; Richardson and Nicklow 2002; Bojic et al. 2004; You et al. 2005; Bojic et al. 2007; Henderson and Demond 2007; Thiruvenkatachari et al. 2008; Bojic et al. 2009). Subsequent works demonstrated that chemical reduction was not a relevant removal mechanism (Noubactep 2011c) and that observed reductive transformations were not the cathodic reaction coupled to anodic iron dissolution (Ghauch 2015; Noubactep 2015, 2016a).

The next step was the demonstration that the volumetric expansive nature of iron corrosion was the main cause of system clogging as $\mathrm{Fe}^{0}$ is corroded by water (Noubactep 2010a, 2013d; Noubactep and Caré 2010a; Noubactep et al. 2010; Noubactep and Caré 2011; Bilardi et al. 2013a). As a consequence, it was established that admixing non-expansive additive $\left(\mathrm{MnO}_{2}\right.$, pumice, sand) to $\mathrm{Fe}^{0}$ is a pre-requisite for sustainable filters. It was also demonstrated that for spherical particles the $\mathrm{Fe}^{0}$ ratio should not exceed $52 \%$ (v/ v). While this threshold value is only valid for spherical particles, it is certain that $100 \% \mathrm{Fe}^{0}$ filters are not sustainable and that the least possible $\mathrm{Fe}^{0}$ ratio should be used (Noubactep and Caré 2010a; Noubactep et al. 2010; Noubactep and Caré, 2011; Miyajima and Noubactep 2012; Btatkeu-K et al. 2014).

The last important result is that the $\mathrm{Fe}^{0} / \mathrm{H}_{2} \mathrm{O}$ system is an ion-selective one (Phukan 2015, Phukan et al. 2015, 2016). The selectivity of the $\mathrm{Fe}^{0} / \mathrm{H}_{2} \mathrm{O}$ system is governed by the positively charged surface of iron oxides at neutral $\mathrm{pH}$ values. This makes $\mathrm{Fe}^{0} / \mathrm{H}_{2} \mathrm{O}$ systems better adsorbents for negatively charged species. However, also positively species are removed by co-precipitation and size exclusion. This conclusion validates the starting hypothesis that $\mathrm{Fe}^{0}$ filters are universal devices for water treatment (Noubactep et al. 2009b).

The next generation $\mathrm{Fe}^{0}$ filters should be based on the state-of-the-art recalled herein as common basis for future investigations. In essence, the next work consists in building a database for the rate constant of $\mathrm{Fe}^{0}$ materials under field conditions. Some laboratory and field designs were recently published (Noubactep 2011d; Noubactep et al. 2012a; Caré et al. 2013; Bilardi et al. 2013a, 2013b; Ndé-Tchoupé et al. 2015; Tepong-Tsindé et al. 2015a; Li et al. 2016). Practical experiments could start with an $\mathrm{Fe}^{0} /$ sand volumetric ratio of 25/75, a $20 \mathrm{~cm}$ high reactive zone, a water flow velocity of $150 \mathrm{~mL}$ day $^{-1}$ and should last for at least $365 \mathrm{~d}$ (1 year). It is important to notice that parallel experiments should be performed with waters differing in their chemical compositions while using the same $\mathrm{Fe}^{0}$ material (Luo et al. 2013). Such experiments even without model contamination will help in characterizing the kinetics of iron corrosion under field conditions as well as the extent of permeability loss. Changes in the $\mathrm{Fe}^{0} / \mathrm{H}_{2} \mathrm{O}$ system should be characterized by systematically 
monitoring: (1) the aqueous $\mathrm{Fe}$ concentration, (2) the $\mathrm{pH}$ value, (3) the water flow velocity, and (4) the electric conductivity. Intermittently adding a contaminant, including an indicator like methylene blue (e.g., $250 \mathrm{~mL}$ every 2 months) and monitoring its behavior would help to discuss the efficiency of the investigated systems. At the end of the term, the success of the $\mathrm{Fe}^{0}$ technology depends largely on testing well-characterized materials under welldefined conditions and building a database describing the experimental results as function of all relevant operational parameters. It is understood that the intrinsic reactivity of each $\mathrm{Fe}^{0}$ material (the 'heart' of the system) should be properly characterized. Only upon such an initial systematic work could fast and reliable method for $\mathrm{Fe}^{0}$ selection be developed (Naseri et al. 2017). Moreover, the testing procedure should last for at least some months to uncover and go beyond the initial rapid corrosion stage of $\mathrm{Fe}^{0}$ (Alamilla et al. 2009; Ndé-Tchoupé et al. 2015; Noubactep 2015; Tepong-Tsindé et al. 2015b).

\section{Philosophical aspect: leave the valley}

A Tibetan saying states: "You must leave the valley of your origin" (to grow spiritually). Its meanings may be translated into the $\mathrm{Fe}^{0}$ literature as "leave the valley of conventional reasoning". The valley of the origin of the $\mathrm{Fe}^{0}$ technology is the thinking system (e.g., $\mathrm{Fe}^{0}$ as reducing agent) that had accompanied its introduction and had never been seriously questioned or any seriously questioning was ignored (Noubactep 2009a, 2009b; Noubactep and Schöner 2009; Noubactep and Caré 2010a; Noubactep 2011a, a; Togue-Kamga et al. 2012; Gatcha-Bandjun and Noubactep 2013; Kobbe-Dama et al. 2013; Noubactep 2013c, 2014b; Nkundimana et al. 2015).

Leaving "the valley of your origin" is stepping outside of your comfortable homeland. By doing this, you are like a refugee, without a secured protecting home. As you have accepted to leave the comfort at home, you may have to see the difference between work and employment. It could be challenging to convince colleagues (including reviewers and editors) that papers that have been published for 20 years contain thinking mistakes (Noubactep 2015). If there is any pressure to publish ("publish or perish"), you may loose your job because of the novelty of your ideas. You will be working for science while being unemployed in your society. These risks have to be parts of your backpack and will help you in hard times. Remember that it was your choice to leave the Valley of Confusion and climb the mountains of knowledge. Also constantly keep in mind that the reward is not immediate (new grant/paper) but longer lasting (contribution to science).

The way out of the valley of confusion almost always goes through another valley which is a more or less long period, when almost nobody understands you (Thesis
Whisperer 2012). If you don't care, you may lose confidence and belief in yourself. But again, remember that you have decided to follow mainstream science and that the valley leads to a higher state of knowledge. Accordingly, even if the intermediate valley seems endless because you are fighting "against the tide", be assured of the beauty of the coming landscape beyond, in the kingdom of mainstream science. The present communication understands itself as the flashlight helping the $\mathrm{Fe}^{0}$ research community out of the valley of confusion.

\section{Conclusions}

The intensive discussion on the suitability, the efficiency and the sustainability of $\mathrm{Fe}^{0}$-based filtration systems for water treatment and environmental remediation is a longstanding one. This discussion is too vast to be resolved by the fragmented approach that has prevailed for the last 25 years. The enormity and urgency of a common starting point for the $\mathrm{Fe}^{0}$ research community are highlighted herein. The primary focus should be on the aqueous iron corrosion ( $\mathrm{Fe}^{0}$ oxidative dissolution) that is common to all evolved systems. This overdue, chemistry-based approach implies a holistic consideration of the problem and would federate efforts on key aspects influencing the design of sustainable systems.

As described herein, there is a strong consensus that $\mathrm{Fe}^{0}$ is a reducing agent for water treatment and environmental remediation. This oversimplification corresponds to a fallacy interchanging 'reduction by $\mathrm{Fe}^{0}$ ' and 'reduction in the presence of $\mathrm{Fe}^{0}$. The former implies that contaminant reduction is the cathodic reaction simultaneous to $\mathrm{Fe}^{0}$ oxidative dissolution (electrochemical reaction). The latter implies that, in aqueous systems, $\mathrm{Fe}^{0}$ generates reducing agents that are the actual contaminant reductants (indirect reduction-chemical reaction). The universality of the indirect reduction mechanism is obvious from the presentation herein. In other words, the $\mathrm{Fe}^{0}$ research community should univocally adopt the indirect reduction concept as the path out of the Valley of Confusion or an avenue to affordable, efficient and sustainable $\mathrm{Fe}^{0}$-based filters.

The holistic approach presented herein, whether perceived as an expansion of the toolkit or a paradigm shift, is attempting to meet the need for more reliable models for the design of efficient and sustainable $\mathrm{Fe}^{0}$ filters. This approach augments and completes available methods to address the limitations of conventional $\mathrm{Fe}^{0}$ filters. This science-based approach also counters the prevailing tendency to separately consider (balkanize) 'contaminant' and ' $\mathrm{Fe}^{0} / \mathrm{H}_{2} \mathrm{O}$ interface'. The circular reasoning created within the $\mathrm{Fe}^{0}$ research community by evidence-based investigations (case-by-case) is proven a time and resources wasting 
approach. On the contrary, results achieved by the holistic approach during the past 5-7 years (from 2010 on) suggest that more success is expected from an open collaboration.

It should be pointed out that while considering established scientific rules that "no model is without limitations", "no model is immune from criticism" and "all models are needed for further research", it has been overseen that the "reducing $\mathrm{Fe}^{0}$ concept' is a fallacy. The future of $\mathrm{Fe}^{0}$ filters relies on the ability of the $\mathrm{Fe}^{0}$ research community to adopt a truly interdisciplinary research implying several branches of basic science (e.g., Chemistry, Chemical Engineering, Electrochemistry, Geochemistry). This interdisciplinary approach will strengthen and speed the development of efficient $\mathrm{Fe}^{0}$ filters.

Acknowledgements The sojourn of $\mathrm{CN}$ in Douala was supported by the German Academic Exchange Service (DAAD—PK 91609183). The manuscript was further improved by the insightful comments of anonymous reviewers.

\section{Compliance with ethical standards}

Conflicts of interest The author declares no conflict of interest.

Open Access This article is distributed under the terms of the Creative Commons Attribution 4.0 International License (http://crea tivecommons.org/licenses/by/4.0/), which permits unrestricted use, distribution, and reproduction in any medium, provided you give appropriate credit to the original author(s) and the source, provide a link to the Creative Commons license, and indicate if changes were made.

\section{References}

Alamilla JL, Espinosa-Medina MA, Sosa E (2009) Modelling steel corrosion damage in soil environment. Corros Sci 51:2628-2638

Allred BJ (2012) Laboratory evaluation of zero valent iron and sulfurmodified iron for agricultural drainage water treatment. Ground Water Monit Remediat 32:81-95

Allred BJ, Racharaks R (2014) Laboratory comparison of four ironbased filter materials for drainage water phosphate treatment. Water Environ Res 86:852-862

Allred BJ, Tost BC (2014) Laboratory comparison of four iron-based filter materials for water treatment of trace element contaminants. Water Environ Res 86:2221-2232

Antia DDJ (2010) Sustainable zero-valent metal (ZVM) water treatment associated with diffusion, infiltration, abstraction and recirculation. Sustainability 2:2988-3073

Attia AA, Girgis BS, Fathy NA (2008) Removal of methylene blue by carbons derived from peach stones by $\mathrm{H}_{3} \mathrm{PO}_{4}$ activation: batch and column studies. Dyes Pigment 76:282-289

Baker M (1934) Sketch of the history of water treatment. J Am Water Works Assoc 26:902-938

Bartzas G, Komnitsas K (2010) Solid phase studies and geochemical modelling of low-cost permeable reactive barriers. J Hazard Mater 183:301-308

Baylis JR (1926) Prevention of corrosion and "red water". J Am Water Works Assoc 15:598-633

Berg M, Luzi S, Trang PTK, Viet PH, Giger W, Stuben D (2006) Arsenic removal from groundwater by household sand filters: comparative field study, model calculations, and health benefits. Environ Sci Technol 40:5567-5573

Bi E, Devlin JF, Huang B (2009) Effects of mixing granular iron with sand on the kinetics of trichloroethylene reduction. Ground Water Monit Remed 29:56-62

Bilardi S, Calabrò PS, Caré S, Moraci N, Noubactep C (2013a) Effect of pumice and sand on the sustainability of granular iron beds for the removal of CuII, NiII, and ZnII. Clean Soil Air Water 41:835-843

Bilardi S, Calabrò PS, Caré S, Moraci N, Noubactep C (2013b) Improving the sustainability of granular iron/pumice systems for water treatment. J Environ Manag 121:133-141

Birke V, Schuett C, Burmeier H, Friedrich H-J (2015) Impact of trace elements and impurities in technical zero-valent iron brands on reductive dechlorination of chlorinated ethenes in groundwater. In: Naidu R, Birke V (ed) Permeable reactive barrier sustainable groundwater remediation, CRC Press: Boca Raton, FL, USA, 2014; pp 87-98

Bischof G (1877) On putrescent organic matter in potable water. I. Proc R S Lond 26:179-184

Bischof G (1878) On putrescent organic matter in potable water. II. Proc R Soc Lond 27:258-261

Bitton GJLHG, Fox JL, Strickland HG (1975) Removal of algae from Florida lakes by magnetic filtration. Appl Microbiol 30:905-908

Bojic A, Purenovic M, Kocic B, Perovic J, Ursic-Jankovic J, Bojic D (2001) The inactivation of escherichia coli by microalloyed aluminium based composite. Facta Universitatis. Phys Chem Technol 2:115-124

Bojic A, Purenovic M, Bojic D (2004) Removal of chromium(VI) from water by micro-alloyed aluminium based composite in flow conditions. Water SA 30:353-359

Bojic A Lj, Purenovic M, Bojic D, Andjelkovic T (2007) Dehalogenation of trihalomethanes by a micro-alloyed aluminium composite under flow conditions. Water SA 33:297-304

Bojic A Lj, Bojic D, Andjelkovic T (2009) Removal of $\mathrm{Cu}^{2+}$ and $\mathrm{Zn}^{2}$ ${ }^{+}$from model wastewaters by spontaneous reduction-coagulation process in flow conditions. J Hazard Mater 168:813-819

Bolm C, Legros J, Le Paih J, Zani L (2004) Iron-catalyzed reactions in organic synthesis. Chem Rev 104:6217-6254

Branston S, Stanley E, Ward J, Keshavarz-Moore E (2011) Study of robustness of filamentous bacteriophages for industrial applications. Biotechnol Bioeng 108:1468-1472

Btatkeu-K BD, Miyajima K, Noubactep C, Caré C (2013) Testing the suitability of metallic iron for environmental remediation: discoloration of methylene blue in column studies. Chem Eng J 215:959-968

Btatkeu-K BD, Olvera-Vargas H, Tchatchueng JB, Noubactep C, Caré S (2014) Characterizing the impact of $\mathrm{MnO}_{2}$ on the efficiency of $\mathrm{Fe}^{0}$-based filtration systems. Chem Eng J 250:416422

Btatkeu-K BD, Tchatchueng JB, Noubactep C, Caré S (2016) Designing metallic iron based water filters: Light from methylene blue discoloration. J Environ Manag 166:567-573

Caré S, Nguyen QT, L'Hostis V, Berthaud Y (2008) Mechanical properties of the rust layer induced by impressed current method in reinforced mortar. Cem Concr Res 38:1079-1091

Caré S, Crane R, Calabrò PS, Ghauch A, Temgoua E, Noubactep C (2013) Modeling the permeability loss of metallic iron water filtration systems. Clear Soil Air Water 41:275-282

CH2M Hill Inc. (CH2 M) (2010). Review of available technologies for the removal of selenium from water. Final report prepared for North American Metals Council, 233 p

Chaudhari S, Banerji T, Kumar PR (2014) Domestic- and communityscale arsenic removal technologies suitable for developing countries. In: Ahuja S (ed) Water reclamation and sustainability,

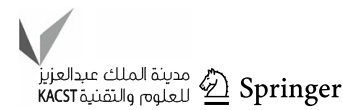


Elsevier Inc., ISBN: 978-0-12-411645-0, 155-182 pp. http://dx. doi.org/10.1016/B978-0-12-411645-0.00007-9

Chen L, Jin S, Fallgren PH, Liu F, Colberg PJS (2013) Passivation of zero-valent iron by denitrifying bacteria and the impact on trichloroethene reduction in groundwater. Water Sci Technol 67:1254-1259

Chen A, Shang C, Shao J, Zhang J, Huang H (2017) The application of iron-based technologies in uranium remediation: a review. Sci Total Environ 575:1291-1306

Chirukuri R, Atmakuru R (2015) Sorption characteristics and persistence of herbicide bispyribac sodium in different global soils. Chemosphere 138:932-939

Comba S, Di Molfetta A, Sethi R (2011) A Comparison between field applications of nano-, micro-, and millimetric zero-valent iron for the remediation of contaminated aquifers. Water Air Soil Pollut 215:595-607

Cornell RM, Schwertmann U (2003) The iron oxides, 2nd edn. Wiley, Weinheim, p 664

Crane RA, Scott TB (2012) Nanoscale zero-valent iron: future prospects for an emerging water treatment technology. J Hazard Mater 211-212:112-125

Crawford RJ, Harding IH, Mainwaring DE (1993a) Adsorption and coprecipitation of single heavy metal ions onto the hydrated oxides of iron and chromium. Langmuir 9:3050-3056

Crawford RJ, Harding IH, Mainwaring DE (1993b) Adsorption and coprecipitation of multiple heavy metal ions onto the hydrated oxides of iron and chromium. Langmuir 9:3057-3062

Crittenden JC, Berrigan JK, Hand DW (1986) Design of rapid smallscale adsorption tests for a constant diffusivity. J Water Pollut Control Fed 58:312-319

Crittenden JC, Berrigan JK, Hand DW, Lykins B (1987) Design of rapid fixed-bed adsorption tests for nonconstant diffusivities. J Environ Eng ASCE 1987(113):243-259

Crittenden JC, Reddy PS, Arora H, Trynoski J, Hand DW, Perram DL, Summers RS (1991) Predicting GAC performance with rapid small-scale column tests. J Am Water Works Assoc 83:77-87

Cundy AB, Hopkinson L, Whitby RLD (2008) Use of iron-based technologies in contaminated land and groundwater remediation: a review. Sci Total Environ 400:42-51

Delatour C, Schmitz G, Maxwell E, Kelland D (1983) Designing HGMS matrix arrays for selective filtration. Magn IEEE Trans 19:2127-2129

Devonshire E (1890) The purification of water by means of metallic iron. J Frankl Inst 129:449-461

Domga R, Togue-Kamga F, Noubactep C, Tchatchueng JB (2015) Discussing porosity loss of $\mathrm{Fe}^{0}$ packed water filters at ground level. Chem Eng J 263:127-134

Dong J, Zhao Y, Zhao R, Zhou R (2010) Effects of pH and particle size on kinetics of nitrobenzene reduction by zero-valent iron. J Environ Sci 22:1741-1747

Duckworth OW, Martin S (2004) Role of molecular oxygen in the dissolution of siderite and rhodochrosite. Geochim Cosmochim Acta 68:607-621

Dutrizac JE, MacDonald RJC (1973) The effect of some impurities on the rate of chalcopyrite dissolution. Can Metall Q 12:409-420

Duveau J (1984) Solids separation and liquid clarification system. US Patent No. 4,427,551. 24 Jan. 1984

Ebelle TC, Makota S, Tepong-Tsindé R, Nassi A, Noubactep C (2016) Metallic iron and the dialogue of the deaf. Fresenius Environ Bull. http://www.prt-parlar.de/ (Accepted)

Eggleston CM, Ehrhardt J-J, Stumm W (1996) Surface structural controls on pyrite oxidation kinetics: an XPS-UPS, STM, and modeling study. Am Mineral 81:1036-1056

Farrell J, Wang J, O’Day P, Conklin M (2001) Electrochemical and spectroscopic study of arsenate removal from water using zerovalent iron media. Environ Sci Technol 35:2026-2032
Fu F, Dionysiou DD, Liu H (2014) The use of zero-valent iron for groundwater remediation and wastewater treatment: a review. J Hazard Mater 267:194-205

Furukawa Y, Kim J-W, Watkins J, Wilkin RT (2002) Formation of ferrihydrite and associated iron corrosion products in permeable reactive barriers of zero-valent iron. Environ Sci Technol 36:5469-5475

Gan EC, Orazem ME (1987) A mathematical model for the corrosion of iron in sulfuric acid. J Electrochem Soc 134:1357-1366

Gatcha-Bandjun N, Noubactep C (2013) Metallic iron for environmental remediation: missing the 'valley of death'. Fresenius Environ Bull 22:2632-2639

Gatcha-Bandjun N, Noubactep C, Benguellah Loura B (2017) Mitigation of contamination in effluents by metallic iron: the role of iron corrosion products. Environ Technol Innov 8:71-83

Ghauch A (2015) Iron-based metallic systems: an excellent choice for sustainable water treatment. Freib Online Geosci 38: 60 pp

Ghauch A, Abou Assi H, Bdeir S (2010) Aqueous removal of diclofenac by plated elemental iron: bimetallic systems. J Hazard Mater 182:64-74

Ghauch A, Abou Assi H, Baydoun H, Tuqan AM, Bejjani A (2011) Fe ${ }^{0}$ based trimetallic systems for the removal of aqueous diclofenac: mechanism and kinetics. Chem Eng J 172:1033-1044

Gheju M (2011) Hexavalent chromium reduction with zero-valent iron (ZVI) in aquatic systems. Water Air Soil Pollut 222:103148

Gheju M, Balcu I (2011) Removal of chromium from Cr(VI) polluted wastewaters by reduction with scrap iron and subsequent precipitation of resulted cations. J Hazard Mater 196:131-138

Gheju M, Balcu I, Vancea C (2016) An investigation of Cr(VI) removal with metallic iron in the co-presence of sand and/or $\mathrm{MnO}_{2}$. J Environ Manag 170:145-151

Gillham RW (2003) Discussion of Papers/Discussion of nano-scale iron for dehalogenation by Evan K. Nyer and David B. Vance (2001), Ground Water Monitoring and Remediation, v. 21, no. 2, pages 41-54. Ground Water Monit Remed 23:6-8

Gottinger AM, McMartin DW, Wild DJ, Moldovan B (2013) Integration of zero valent iron sand beds into biological treatment systems for uranium removal from drinking water wells in rural Canada. Can J Civ Eng 40:945-950

Gould JP (1982) The kinetics of hexavalent chromium reduction by metallic iron. Water Res 16:871-877

Griffin GL (1984) A simple phase transition model for metal passivation kinetics. J Electrochem Soc 131:18-21

Guan X, Sun Y, Qin H, Li J, Lo IMC, He D, Dong H (2015) The limitations of applying zero-valent iron technology in contaminants sequestration and the corresponding countermeasures: the development in zero-valent iron technology in the last two decades (1994-2014). Water Res 45:224-248

Guo X, Yang Z, Dong H, Guan X, Ren Q, Lv X, Jin X (2016) Simple combination of oxidants with zero-valent-iron (ZVI) achieved very rapid and highly efficient removal of heavy metals from water. Water Res 88:671-680

Han L, Yang L, Wang H, Hu X, Chen Z, Hu C (2016) Sustaining reactivity of $\mathrm{Fe}^{0}$ for nitrate reduction via electron transfer between dissolved $\mathrm{Fe}^{2+}$ and surface iron oxides. J Hazard Mater 308:208-221

Henderson AD, Demond AH (2007) Long-term performance of zerovalent iron permeable reactive barriers: a critical review. Environ Eng Sci 24:401-423

Henderson AD, Demond AH (2011) Impact of solids formation and gas production on the permeability of ZVI PRBs. J Environ Eng 137:689-696

Hindle KT, Jackson SD, Stirling D, Webb G (2006) The hydrogenation of para-toluidine over rhodium/silica; the effect of metal particle size and support texture. J Catal 241:417-425 
Holmes PR, Crundwell FK (1995) Kinetic aspects of galvanic interactions between minerals during dissolution. Hydrometallurgy 39:353-375

Huang YH, Zhang TC (2006) Reduction of nitrobenzene and formation of corrosion coatings in zerovalent iron systems. Water Res 40:3075-3082

Huang YH, Tang CL, Zeng H (2012) Removing molybdate from water using a hybridized zero-valent iron/magnetite/Fe(II) treatment system. Chem Eng J 200:205-263

Huang YH, Peddi PK, Zeng H, Tang CL, Teng XJ (2013a) Pilot-scale demonstration of the hybrid zero-valent iron process for treating flue-gas-desulfurization wastewater: part I. Water Sci Technol 67:16-23

Huang YH, Peddi PK, Zeng H, Tang CL, Teng XJ (2013b) Pilot-scale demonstration of the hybrid zero-valent iron process for treating flue-gas-desulfurization wastewater: part II. Water Sci Technol 67:239-246

Hung H-M, Ling FH, Hoffmann MR (2000) Kinetics and mechanism of the enhanced reductive degradation of nitrobenzene by elemental iron in the presence of ultrasound. Environ Sci Technol 34:1758-1763

Hussam A (2009) Contending with a development disaster: SONO filters remove arsenic from well water in Bangladesh. Innovations 4:89-102

Hussam A, Munir AKM (2007) A simple and effective arsenic filter based on composite iron matrix: development and deployment studies for groundwater of Bangladesh. J Environ Sci Health A 42:1869-1878

James BR, Rabenhorst MC, Frigon GA (1992) Phosphorus sorption by peat and sand amended with iron oxides or steel wool. Water Environ Res 64:699-705

Jarrard RD (2001) Scientific methods: an online book. http://content. lib.utah.edu/cdm/ref/collection/uspace/id/4073 (Access May 25, 2016)

Jia Y, Aagaard P, Breedveld GD (2007) Sorption of triazoles to soil and iron minerals. Chemosphere 67:250-258

Jiao Y, Qiu C, Huang L, Wu K, Ma H, Chen S, Ma L, Wu L (2009) Reductive dechlorination of carbon tetrachloride by zero-valent iron and related iron corrosion. Appl Catal B Environ 91:434440

Johnson TL, Scherer MM, Tratnyek PG (1996) Kinetics of halogenated organic compound degradation by iron metal. Environ Sci Technol 30:2634-2640

Ju Y, Liu X, Li Z, Kang J, Wang X, Zhang Y, Fang J, Dionysiou DD (2015a) Environmental application of millimetre-scale sponge iron $\left(\mathrm{s}-\mathrm{Fe}^{0}\right)$ particles (I): pretreatment of cationic triphenylmethane dyes. J Hazard Mater 283:469-479

Ju Y, Liu X, Liu R, Yu Y, Li G, Wang X, Yang Y, Wei D, Fang J, Dionysiou DD (2015b) Environmental application of millimeterscale sponge iron $\left(\mathrm{s}-\mathrm{Fe}^{0}\right)$ particles (II): the effect of surface copper. J Hazard Mater 287:325-334

Ju Y, Yu Y, Wang X, Zhang S, Liu R, Fu J, Han J, Fang J, Dionysiou DD (2015c) Environmental application of millimetre-scale sponge iron $\left(\mathrm{s}-\mathrm{Fe}^{0}\right)$ particles (III): the effect of surface silver. J Hazard Mater 299:618-629

Kang S-H, Choi W (2009) Response to comment on "Oxidative degradation of organic compounds using zero-valent iron in the presence of natural organic matter serving as an electron shuttle”. Environ Sci Technol 43:3966-3967

Karavasteva M (2005) Kinetics and deposit morphology of copper cementation onto zinc, iron and aluminium. Hydrometallurgy 76:149-152

Karottu-Ansaf KV, Ambika S, Manivannan-Nambi I (2016) Performance enhancement of zero valent iron based systems using depassivators: optimization and kinetic mechanisms. Water Res 102:436-444
Karschunke K, Gorny M, Jekel M (2000) Arsenic removal by corrosion-induced adsorption. Vom Wasser 95:215-222

Khan AH, Rasul SB, Munir AKM, Habibuddowla M, Alauddin M, Newaz SS, Hussam A (2000) Appraisal of a simple arsenic removal method for groundwater of Bangladesh. J Environ Sci Health A 35:1021-1041

Kiéné L, Lu W, Lévi Y (1998) Relative importance of the phenomena responsible for chlorine decay in drinking water distribution system. Water Sci Technol 38:219-227

Kivman GY, Snegireva NS, Yavorskaya ES (1979) Sterilization of drugs by filters. Pharm Chem J 13:1187-1196

Kobbe-Dama N, Noubactep C, Tchatchueng JB (2013) Metallic iron for water treatment: prevailing paradigm hinders progress. Fresenius Environ Bull 22:2953-2957

Kowalski KP, Søgaard EG (2014) Implementation of zero-valent iron (ZVI) into drinking water supply-role of the ZVI and biological processes. Chemosphere 117:108-114

Kumar R, Sinha A (2017) Biphasic reduction model for predicting the impacts of dye-bath constituents on the reduction of tris-azo dye Direct Green-1 by zero valent iron $\left(\mathrm{Fe}^{0}\right)$. J Environ Sci 52:160 169

Lackovic JA, Nikolaidis NP, Dobbs GM (2000) Inorganic arsenic removal by zero-valent iron. Environ Eng Sci 17:29-39

Lasek JA (2014) Investigations of the reduction of NO to $\mathrm{N}_{2}$ by reaction with $\mathrm{Fe}$ under fuel-rich and oxidative atmosphere. Heat Mass Transf 50:933-943

Laskowski T, Swietlik J, Raczyk-Stanislawiak U, Piszora P, Sroka M, Olejnik A, Nawrocki J (2015) A cast iron filings based model for dynamic investigation of corrosion and its compatibility with the real water distribution network. Desalination Water Treat. doi:10.1080/19443994.2015.1021848

Lavine BK, Auslander G, Ritter J (2001) Polarographic studies of zero valent iron as a reductant for remediation of nitroaromatics in the environment. Microchem J 70:69-83

Lazzari L (2008) General aspects of corrosion., Chapter 9.1, Vol. V, Encyclopedia of hydrocarbons, Istituto Enciclopedia Italiana, Rome, Italy, pp 485-505

Le C, Wu JH, Deng SB, Li P, Wang XD, Zhu NW, Wu PX (2011) Effects of common dissolved anions on the reduction of parachloronitrobenzene by zero-valent iron in groundwater. Water Sci Technol 63:1485-1490

Lee G, Rho S, Jahng D (2004) Design considerations for groundwater remediation using reduced metals. Korean J Chem Eng 21:621628

Lee H, Yoo H-Y, Choi J, Nam I-H, Lee S, Lee S, Kim J-H, Lee C, Lee J (2014) Oxidizing capacity of periodate activated with ironbased bimetallic nanoparticles. Environ Sci Technol 48:80868093

Leupin OX, Hug SJ (2005) Oxidation and removal of arsenic (III) from aerated groundwater by filtration through sand and zerovalent iron. Water Res 39:1729-1740

Li L, Benson CH (2010) Evaluation of five strategies to limit the impact of fouling in permeable reactive barriers. J Hazard Mater 181:170-180

Li L, Benson CH, Lawson EM (2006) Modeling porosity reductions caused by mineral fouling in continuous-wall permeable reactive barriers. J Contam Hydrol 83:89-121

Li J, Wei L, Li Y, Bi N, Song F (2011) Cadmium removal from wastewater by sponge iron sphere prepared by hydrogen reduction. J Environ Sci 23:S114-S118

Li J, Qin H, Guan X (2015) Premagnetization for enhancing the reactivity of multiple zerovalent iron samples toward various contaminants. Environ Sci Technol 49:14401-14408

Li S, Ding Y, Wang W, Lei H (2016) A facile method for determining the $\mathrm{Fe}(0)$ content and reactivity of zero valent iron. Anal Methods 8:1239-1248 
Liang C, Guo Y-Y (2010) Mass transfer and chemical oxidation of naphthalene particles with zerovalent iron activated persulfate. Environ Sci Technol 44:8203-8208

Liger E, Charlet L, Van Cappellen P (1999) Surface catalysis of uranium(VI) reduction by iron(II). Geochim Cosmochim Acta 63:2939-2955

Lin Y-T, Liang C, Yu C-W (2016) Trichloroethylene degradation by various forms of iron activated persulfate oxidation with or without the assistance of ascorbic acid. Ind Eng Chem Res 55:2302-2308

Lipczynska-Kochany E, Harms S, Milburn R, Sprah G, Nadarajah N (1994) Degradation of carbon tetrachloride in the presence of iron and sulphur containing compounds. Chemosphere 29:1477-1489

Liu X, Millero FJ (1999) The solubility of iron hydroxide in sodium chloride solutions. Geochim Cosmochim Acta 63:3487-3497

Liu R, Zhu J, Yu Z, Joshi D, Zhang H, Lin W, Yang M (2014) Molecular analysis of long-term biofilm formation on PVC and cast iron surfaces in drinking water distribution system. J Environ Sci 26:865-874

Lu X, Li M, Deng H, Lin P, Matsumoto MR, Liu X (2016) Application of electrochemical depassivation in PRB systems to recovery $\mathrm{Fe}^{0}$ reactivity. Front Environ Sci Eng. doi:10.1007/ s11783-016-0843-0

Luo P, Bailey EH, Mooney SJ (2013) Quantification of changes in zero valent iron morphology using X-ray computed tomography. J Environ Sci 25:2344-2351

Mackenzie PD, Horney DP, Sivavec TM (1999) Mineral precipitation and porosity losses in granular iron columns. J Hazard Mater 68:1-17

Madaffari MG (2015) New mixtures to be used in permeable reactive barrier for heavy-metals contaminated groundwater remediation: long-term removal efficiency and hydraulic behavior. Ph.D. Thesis, Ecole Centrale Paris, 290 pp

Marsh K, Bugusu B (2007) Food packaging-roles, materials, and environmental issues. J Food Sci 72:R39-R55

Matheson LJ, Tratnyek PG (1994) Reductive dehalogenation of chlorinated methanes by iron metal. Environ Sci Technol 28:2045-2053

McGeough KL, Kalin RM, Myles P (2007) Carbon disulfide removal by zero valent iron. Environ Sci Technol 41:4607-4612

Mehta AP, Murr LE (1983) Fundamental studies of the contribution of galvanic interaction to acid-bacterial leaching of mixed metal sulphides. Hydrometallurgy 9:235-256

Miehr R, Tratnyek GP, Bandstra ZJ, Scherer MM, Alowitz JM, Bylaska JE (2004) Diversity of contaminant reduction reactions by zerovalent iron: role of the reductate. Environ Sci Technol 38:139-147

Mitchell G, Poole P, Segrove HD (1955) Adsorption of methylene blue by high-silica sands. Nature 176:1025-1026

Miyajima K (2012) Optimizing the design of metallic iron filters for water treatment. Freib Online Geosci 32, 60 pp

Miyajima K, Noubactep C (2012) Effects of mixing granular iron with sand on the efficiency of methylene blue discoloration. Chem Eng J 200:433-438

Miyajima K, Noubactep C (2015) Characterizing the impact of sand addition on the efficiency of granular iron for water treatment. Chem Eng J 262:891-896

Moraci N, Calabrò PS (2010) Heavy metals removal and hydraulic performance in zero-valent iron/pumice permeable reactive barriers. J Environ Manag 91:2336-2341

Moraci N, Ielo D, Bilardi S, Calabrò PS (2016) Modelling long term hydraulic conductivity behaviour of zero valent iron column tests for PRB design. Can Geotech J 53:946-961

Morrison SJ, Metzler DR, Dwyer BP (2002) Removal of As, Mn, Mo, $\mathrm{Se}, \mathrm{U}, \mathrm{V}$ and $\mathrm{Zn}$ from groundwater by zero-valent iron in a passive treatment cell: reaction progress modeling. J Contam Hydrol 56:99-116

Morrison SJ, Mushovic PS, Niesen PL (2006) Early breakthrough of molybdenum and uranium in a permeable reactive barrier. Environ Sci Technol 40:2018-2024

Mwakabona HT, Ndé-Tchoupé AI, Njau KN, Noubactep C, Wydra KD (2017) Metallic iron for safe drinking water provision: considering a lost knowledge. Water Res 117:127-142

Naidu R (2013) Recent advances in contaminated site remediation. Water Air Soil Pollut 224:1-11. doi:10.1007/s11270-013-1705-z

Naidu R, Birke V (2015) "Permeable reactive barrier: sustainable groundwater remediation". CRC Press 2014, eBook ISBN: 978-1-4822-2448-1, 333 pp

Naseri E, Ndé-Tchoupé AI, Mwakabona HT, Nanseu-Njiki CP, Noubactep C, Njau KN, Wydra KD (2017) Making Fe ${ }^{0}$-based filters a universal solution for safe drinking water provision. Sustainability 9:1224. doi:10.3390/su9071224

Ndé-Tchoupé AI, Crane RA, Mwakabona HT, Noubactep C, Njau K (2015) Technologies for decentralized fluoride removal: testing metallic iron based filters. Water 7:6750-6774

Nesic S (2007) Key issues related to modelling of internal corrosion of oil and gas pipelines-A review. Corros Sci 49:4308-4338

Neumann A, Kaegi R, Voegelin A, Hussam A, Munir AKM, Hug SJ (2013) Arsenic removal with composite iron matrix filters in Bangladesh: a field and laboratory study. Environ Sci Technol 47:4544-4554

Nkundimana E, Noubactep C, Uwamariya V (2015) Metallic iron for water treatment and environmental remediation: a handout to young researchers. Fresenius Environ Bull 24:4842-4846

Noubactep C (2006) Contaminant reduction at the surface of elemental iron: the end of a myth, vol 31. Wissenschaftliche Mitteilungen, Freiberg, pp 173-179 (ISSN 1433-128)

Noubactep C (2007) Processes of contaminant removal in " $\mathrm{Fe}^{0}-\mathrm{H}_{2} \mathrm{O}$ " systems revisited: the importance of co-precipitation. Open Environ Sci 1:9-13

Noubactep C (2008) A critical review on the mechanism of contaminant removal in $\mathrm{Fe}^{0}-\mathrm{H}_{2} \mathrm{O}$ systems. Environ Technol 29:909-920

Noubactep C (2009a) An analysis of the evolution of reactive species in $\mathrm{Fe}^{0} / \mathrm{H}_{2} \mathrm{O}$ systems. J Hazard Mater 168:1626-1631

Noubactep C (2009b) On the operating mode of bimetallic systems for environmental remediation. J Hazard Mater 164:394-395

Noubactep C (2009c) On the validity of specific rate constants $\left(\mathrm{k}_{\mathrm{SA}}\right)$ in $\mathrm{Fe}^{0} / \mathrm{H}_{2} \mathrm{O}$ systems. J Hazard Mater 164:835-837

Noubactep C (2010a) The fundamental mechanism of aqueous contaminant removal by metallic iron. Water SA 36:663-670

Noubactep C (2010b) Metallic iron for safe drinking water worldwide. Chem Eng J 165:740-749

Noubactep C (2010c) The suitability of metallic iron for environmental remediation. Environ Progr Sust En. 29:286-291

Noubactep C (2010d) Elemental metals for environmental remediation: learning from cementation process. J Hazard Mater 181:1170-1174

Noubactep C (2011a) Metallic iron for safe drinking water production. Freib Online Geosci 27: 38 pp

Noubactep C (2011b) Aqueous contaminant removal by metallic iron: is the paradigm shifting? Water SA 37:419-426

Noubactep C (2011c) Metallic iron for water treatment: a knowledge system challenges mainstream science. Fresenius Environ Bull 20:2632-2637

Noubactep C (2011d) Characterizing the reactivity of metallic iron in $\mathrm{Fe}^{0} / \mathrm{U}^{\mathrm{VI}} / \mathrm{H}_{2} \mathrm{O}$ systems by long-term column experiments. Chem Eng J 171:393-399

Noubactep C (2012a) Investigating the processes of contaminant removal in $\mathrm{Fe}^{0} / \mathrm{H}_{2} \mathrm{O}$ systems. Korean J Chem Eng 29:1050-1056 
Noubactep C (2012b) Characterizing the reactivity of metallic iron in $\mathrm{Fe}^{0} / \mathrm{As}$-rock $/ \mathrm{H}_{2} \mathrm{O}$ systems by long-term column experiments. Water SA 38:511-517

Noubactep C (2013a) Relevant reducing agents in remediation $\mathrm{Fe}^{0}$ / $\mathrm{H}_{2} \mathrm{O}$ systems. Clean Soil Air Water 41:493-502

Noubactep C (2013b) Metallic iron for water treatment: a critical review. Clean Soil Air Water 41:702-710

Noubactep C (2013c) Metallic iron for environmental remediation: the long walk to evidence. Corros Rev 31:51-59

Noubactep C (2013d) On the suitability of admixing sand to metallic iron for water treatment. Int J Environ Pollut Solut 1:22-36

Noubactep C (2014a) Flaws in the design of $\mathrm{Fe}(0)$-based filtration systems? Chemosphere 117:104-107

Noubactep C (2014b) Metallic iron for water treatment: Healing a research community. J N Dev Chem 1: 5 pp

Noubactep C (2015) Metallic iron for environmental remediation: a review of reviews. Water Res 45:114-123

Noubactep C (2016a) Predicting the hydraulic conductivity of metallic iron filters: modeling gone astray. Water. doi:10.3390/ w8040162

Noubactep C (2016b) Research on metallic iron for environmental remediation: stopping growing sloppy science. Chemosphere 153:528-530

Noubactep C (2016c) No scientific debate in the zero-valent iron literature. Clean Soil Air Water 44:330-332

Noubactep C (2016d) Designing metallic iron packed-beds for water treatment: a critical review. Clean Soil Air Water 44:411-421

Noubactep C (2016e) The operating mode of $\mathrm{Fe}^{0} / \mathrm{H}_{2} \mathrm{O}$ systems: hidden truth or repeated nonsense? Fresenius Environ Bull (Accepted 24.07.2016-F-2015-180)

Noubactep C, Caré S (2010a) Dimensioning metallic iron beds for efficient contaminant removal. Chem Eng J 163:454-460

Noubactep C, Caré S (2010b) On nanoscale metallic iron for groundwater remediation. J Hazard Mater 182:923-927

Noubactep C, Caré S (2011) Designing laboratory metallic iron columns for better result comparability. J Hazard Mater 189:809-813

Noubactep C, Schöner A (2009) $\mathrm{Fe}^{0}$-based alloys for environmental remediation: thinking outside the box. J Hazard Mater 165:1210-1214

Noubactep C, Meinrath G, Dietrich P, Merkel B (2003) Mitigating uranium in ground water: prospects and limitations. Environ Sci Technol 37:4304-4308

Noubactep C, Meinrath G, Merkel JB (2005a) Investigating the mechanism of uranium removal by zerovalent iron materials. Environ Chem 2:235-242

Noubactep C, Meinrath G, Dietrich P, Sauter M, Merkel B (2005b) Testing the suitability of zerovalent iron materials for reactive Walls. Environ Chem 2:71-76

Noubactep C, Schöner A, Meinrath G (2006) Mechanism of uranium (VI) fixation by elemental iron. J Hazard Mater 132:202-212

Noubactep C, Licha T, Scott TB, Fall M, Sauter M (2009a) Exploring the influence of operational parameters on the reactivity of elemental iron materials. J Hazard Mater 172:943-951

Noubactep C, Schöner A, Woafo P (2009b) Metallic iron filters for universal access to safe drinking water. Clean Soil Air Water 37:930-937

Noubactep C, Caré S, Togue-Kamga F, Schöner A, Woafo P (2010) Extending service life of household water filters by mixing metallic iron with sand. Clean Soil Air Water 38:951-959

Noubactep C, Caré S, Crane RA (2012a) Nanoscale metallic iron for environmental remediation: prospects and limitations. Water Air Soil Pollut 223:1363-1382

Noubactep C, Temgoua E, Rahman MA (2012b) Designing ironamended biosand filters for decentralized safe drinking water provision. Clean Soil Air Water 40:798-807
O`Hannesin SF, Gillham RW (1998) Long-term performance of an in situ "iron wall" for remediation of VOCs. Ground Water 36:164-170

Obiri-Nyarko F, Grajales-Mesa SJ, Malina G (2014) An overview of permeable reactive barriers for in situ sustainable groundwater remediation. Chemosphere 111:243-259

Odziemkowski M (2009) Spectroscopic studies and reactions of corrosion products at surfaces and electrodes. Spectrosc Prop Inorg Organomet Compd 40:385-450

Phillips DH, Van Nooten T, Bastiaens L, Russell MI, Dickson K, Plant S, Ahad JM, Newton T, Elliot T, Kalin RM (2010) Ten year performance evaluation of a field-scale zero-valent iron permeable reactive barrier installed to remediate trichloroethene contaminated groundwater. Environ Sci Technol 44:3861-3869

Phukan M (2015) Characterizing the $\mathrm{Fe}^{0}$ /sand system by the extent of dye discoloration. Freib Online Geosci 42: $80 \mathrm{pp}$

Phukan M, Noubactep C, Licha T (2015) Characterizing the ionselective nature of $\mathrm{Fe}^{0}$-based filters using azo dyes. Chem Eng J 259:481-491

Phukan M, Noubactep C, Licha T (2016) Characterizing the ionselective nature of $\mathrm{Fe}^{0}$-based filters using three azo dyes in batch systems. J Environ Chem Eng 4:65-72

Pilling NB, Bedworth RE (1923) The oxidation of metals at high temperatures. J Inst Metals 29:529-591

Pokhrel D, Viraraghavan T (2008) Arsenic removal in an iron oxidecoated fungal biomass column: analysis of breakthrough curves. Biores Technol 99:2067-2071

Pokhrel D, Viraraghavan T (2009) Biological filtration for removal of arsenic from drinking water. J Environ Manag 90:1956-1961

Pokhrel D, Viraraghavan T, Braul L (2005) Evaluation of treatment systems for the removal of arsenic from groundwater. Pract Period Hazard Toxic Radioact Waste Manag 9:152-157

Pokhrel D, Bhandari BS, Viraraghavan T (2009) Arsenic contamination of groundwater in the Terai region of Nepal: an overview of health concerns and treatment options. Environ Int 35:157-161

Popat V, Padhiyar N (2013) Kinetic study of bechamp process for P-nitrotoluene reduction to P-toluidine. Int J Chem Eng Appl 4:401-405

Rahman MA, Karmakar S, Salama H, Gactha-Bandjun N, Btatkeu-K $\mathrm{BD}$, Noubactep $\mathrm{C}$ (2013) Optimising the design of $\mathrm{Fe}^{0}$-based filtration systems for water treatment: the suitability of porous iron composites. J Appl Solut Chem Model 2:165-177

Raman CD, Kanmani S (2016) Textile dye degradation using nano zero valent iron: a review. J Environ Manag 177:341-355

Reardon JE (1995) Anaerobic corrosion of granular iron: measurement and interpretation of hydrogen evolution rates. Environ Sci Technol 29:2936-2945

Reardon JE (2005) Zerovalent irons: styles of corrosion and inorganic control on hydrogen pressure buildup. Environ Sci Technol 39:7311-7317

Richardson JP, Nicklow JW (2002) In situ permeable reactive barriers for groundwater contamination. Soil Sediment Contam 11:241-268

Ruhl AS, Weber A, Jekel M (2012a) Influence of dissolved inorganic carbon and calcium on gas formation and accumulation in iron permeable reactive barriers. J Contam Hydrol 142:22-32

Ruhl AS, Ünal N, Jekel M (2012b) Evaluation of two-component Fe (0) fixed bed filters with porous materials for reductive dechlorination. Chem Eng J 209:401-406

Saha B, Das S, Saikia J, Das G (2011) Preferential and enhanced adsorption of different dyes on iron oxide nanoparticles: a comparative study. J Phys Chem C 115:8024-8033

Sarr D (2001) Zero-valent-iron permeable reactive barriers-how long will they last? Remediation 11:1-18

Scherer MM, Richter S, Valentine RL, Alvarez PJJ (2000) Chemistry and microbiology of permeable reactive barriers for in situ groundwater clean up. Rev Environ Sci Technol 30:363-411

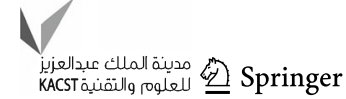


Schwertmann U (1991) Solubility and dissolution of iron oxides. Plant Soil 130:1-25

Segura Y, Martínez F, Melero JA, Fierro JLG (2015) Zero valent iron (ZVI) mediated Fenton degradation of industrial wastewater: treatment performance and characterization of final composites. Chem Eng J 269:298-305

Shrimpton HK, Blowes DW, Ptacek CJ (2015) Fractionation of selenium during selenate reduction by granular zerovalent iron. Environ Sci Technol 49:11688-11696

Sikora E, Macdonald DD (2000) The passivity of iron in the presence of ethylenediaminetetraacetic acid I. General electrochemical behavior. J Electrochem Soc 147:4087-4092

Sinde E, Carballo J (2000) Attachment of Salmonella spp. and Listeria monocytogenes to stainless steel, rubber and polytetrafluorethylene: the influence of free energy and the effect of commercial sanitizers. Food Microbiol 17:439-447

Sleiman N, Deluchat V, Wazne V, Mallet M, Courtin-Nomade A, Kazpard V, Baudu M (2016) Phosphate removal from aqueous solution using ZVI/sand bed reactor: behavior and mechanism. Water Res 99:56-65

Song X, Chen Z, Wang X, Zhang S (2017) Ligand effects on nitrate reduction by zero-valent iron: role of surface complexation. Water Res 114:218-227

Statham TM, Stark SC, Snape I, Stevens GW, Mumford KA (2016) A permeable reactive barrier (PRB) media sequence for the remediation of heavy metal and hydrocarbon contaminated water: a field assessment at Casey Station, Antarctica. Chemosphere 147:368-375

Stratmann M, Müller J (1994) The mechanism of the oxygen reduction on rust-covered metal substrates. Corros Sci 1994 (36):327-359

Sun Y, Li J, Huang T, Guan X (2016) The influences of iron characteristics, operating conditions and solution chemistry on contaminants removal by zero-valent iron: a review. Water Res 100:277-295

Tepong-Tsindé R, Crane R, Noubactep C, Nassi A, Ruppert H (2015a) Testing metallic iron filtration systems for decentralized water treatment at pilot scale. Water 7:868-897

Tepong-Tsindé R, Phukan M, Nassi A, Noubactep C, Ruppert H (2015b) Validating the efficiency of the MB discoloration method for the characterization of $\mathrm{Fe}^{0} / \mathrm{H}_{2} \mathrm{O}$ systems using accelerated corrosion by chloride ions. Chem Eng J 279:353-362

Thesis Whisperer (2012) The valley of shit. https://thesiswhisperer. com/2012/05/08/the-valley-of-shit/. Access May 30, 2016

Thiruvenkatachari R, Vigneswaran S, Naidu R (2008) Permeable reactive barrier for groundwater remediation. J Ind Eng Chem $14: 145-156$

Togue-Kamga F, Btatkeu KBD, Noubactep C, Woafo P (2012) Metallic iron for environmental remediation: back to textbooks. Fresenius Environ Bull 21:1992-1997

Tratnyek PG (2002) Keeping up with all that literature: the ironrefs database turns 500. Ground Water Monit R 22:92-94

Tratnyek PG, Salter AJ (2010) Response to comment on "degradation of 1,2,3-trichloropropane (TCP): hydrolysis, elimination, and reduction by iron and zinc". Environ Sci Technol 44:3198-3199

Tseng CL, Yang MH, Lin CC (1984) Rapid determination of cobalt60 in sea water with steel wool adsorption. J Radioanal Nucl Chem Lett 85:253-260

Twidwell LG, McCloskey J (2011) A literature guide for removing arsenic from aqueous solution and long-term product storage. J Miner Metals Mater Soc 63:94-100

Ulsamer S (2011) A model to characterize the kinetics of dechlorination of tetrachloroethylene and trichloroethylene by a zero valent iron permeable reactive barrier. Master thesis, Worcester Polytechnic Institute, Worcester, UK

Van Craenenbroeck W (1998) Easton and Anderson and the water supply of Antwerp (Belgium). Ind Archaeol Rev 20:105-116

van Genuchten CM, Bandaru SRS, Surorova E, Amrose SE, Gadgil AJ, Peña J (2016) Formation of macroscopic surface layers on Fe (0) electrocoagulation electrodes during an extended field trial of arsenic treatment. Chemosphere 153:270-279

Wan W, Pepping TJ, Banerji T, Chaudhari S, Giammar DE (2016) Effects of water chemistry on arsenic removal from drinking water by electrocoagulation. Water Res 45:384-392

Weber EJ (1996) Iron-mediated reductive transformations: investigation of reaction mechanism. Environ Sci Technol 30:716-719

Westerhoff P, James J (2003) Nitrate removal in zero-valent iron packed columns. Water Res 37:1818-1830

Westerhoff PK, Highfield DE, Badruzzaman M, Yoon Y (2005) Rapid small scale column tests for arsenic removal in iron oxide packed bed columns. J Environ Eng ASCE 131:262-272

Westerhoff P, De Haan M, Martindale A, Badruzzaman M (2006) Arsenic adsorptive media technology selection strategies. Water Qual Res J Canada 41:171-184

White AF, Peterson ML (1996) Reduction of aqueous transition metal species on the surfaces of $\mathrm{Fe}(\mathrm{II})$-containing oxides. Geochim Cosmochim Acta 60:3799-3814

Wilkin RT, Acree SD, Ross RR, Puls RW, Lee TR, Woods LL (2014) Fifteen-year assessment of a permeable reactive barrier for treatment of chromate and trichloroethylene in groundwater. Sci Total Environ 468-469:186-194

Xie L, Shang C (2007) The effects of operational parameters and common anions on the reactivity of zero-valent iron in bromate reduction. Chemosphere 66:1652-1659

Xu B, Jia M, Men J (2013) Preparation of modified sponge iron and kinetics of deoxygenization by it. Arab J Sci Eng 38:3259-3266

Xu C, Zhang B, Zhu L, Lin S, Sun X, Jiang Z, Tratnyek PG (2016) Sequestration of antimonite by zerovalent iron: using weak magnetic field effects to enhance performance and characterize reaction mechanisms. Environ Sci Technol 50:1483-1491

Yang Z, Xu H, Shan C, Jiang C, Pan C (2017) Effects of brining on the corrosion of ZVI and its subsequent $\mathrm{As}(\mathrm{III} / \mathrm{V})$ and $\mathrm{Se}(\mathrm{IV} / \mathrm{VI})$ removal from water. Chemosphere 170:251-259

Yao K-M, Habibian MT, O'melia CR (1971) Water and waste water filtration: concepts and applications. Environ Sci Technol 5:1105-1112

Yi ZJ, Xu JS, Chen MS, Li W, Yao J, Chen HL, Wang F (2013) Removal of uranium(VI) from aqueous solution using sponge iron. J Radioanal Nucl Chem 298:955-961

You Y, Han J, Chiu PC, Jin Y (2005) Removal and inactivation of waterborne viruses using zerovalent iron. Environ Sci Technol 39:9263-9269

Zhang Z, Stout JE, Yu VL, Vidic R (2008) Effect of pipe corrosion scales on chlorine dioxide consumption in drinking water distribution systems. Water Res 42:129-136

Zou J, Cannon FS, Chen W, Dempsey BA (2010) Improved removal of arsenic from groundwater using pre-corroded steel and iron tailored granular activated carbon. Water Sci Technol 61:441453

Zou Y, Wang X, Khan A, Wang P, Liu Y, Alsaedi A, Hayat T, Wang $X$ (2016) Environmental remediation and application of nanoscale zero-valent iron and its composites for the removal of heavy metal ions: a review. Environ Sci Technol 50:7290 7304 